\title{
Transient P2X7 Receptor Antagonism Produces Lasting Reductions in Spontaneous Seizures and Gliosis in Experimental Temporal Lobe Epilepsy
}

\author{
๑DAlba Jimenez-Pacheco, ${ }^{1}$ @Miguel Diaz-Hernandez, ${ }^{3}$ @Marina Arribas-Blázquez, ${ }^{4,5}$ Amaya Sanz-Rodriguez, ${ }^{1}$ \\ Luis A. Olivos-Oré, ${ }^{4,5}$ Antonio R. Artalejo, ${ }^{4,5}$ Mariana Alves, ${ }^{1}$ Michael Letavic, ${ }^{6}$ M. Teresa Miras-Portugal, ${ }^{3,5}$ \\ ㅁonan M. Conroy, ${ }^{2}$ Norman Delanty, ${ }^{7}$ Michael A. Farrell, ${ }^{7}$ Donncha F. 0 'Brien, ${ }^{7}$ Anindya Bhattacharya, ${ }^{6}$ \\ Tobias Engel, ${ }^{1 \star}$ and David C. Henshall ${ }^{1 \star}$ \\ ${ }^{1}$ Department of Physiology and Medical Physics, and 2Division of Population Health Sciences, Royal College of Surgeons in Ireland, Dublin 2, Ireland, \\ Departments of ${ }^{3}$ Biochemistry and ${ }^{4}$ Toxicology and Pharmacology, Faculty of Veterinary Medicine, and ${ }^{5}$ Instituto de Investigación en Neuroquímica, \\ Universidad Complutense de Madrid, Madrid 28040, Spain, ${ }^{6}$ Janssen Research \& Development, LLC, Neuroscience, La Jolla, California 92121 , and \\ ${ }^{7}$ Beaumont Hospital, Beaumont, Dublin 9, Ireland
}

Neuroinflammation is thought to contribute to the pathogenesis and maintenance of temporal lobe epilepsy, but the underlying cell and molecular mechanisms are not fully understood. The P2X7 receptor is an ionotropic receptor predominantly expressed on the surface of microglia, although neuronal expression has also been reported. The receptor is activated by the release of ATP from intracellular sources that occurs during neurodegeneration, leading to microglial activation and inflammasome-mediated interleukin $1 \beta$ release that contributes to neuroinflammation. Using a reporter mouse in which green fluorescent protein is induced in response to the transcription of $P 2 r x 7$, we show that expression of the receptor is selectively increased in CA1 pyramidal and dentate granule neurons, as well as in microglia in mice that developed epilepsy after intra-amygdala kainic acid-induced status epilepticus. P2X7 receptor levels were increased in hippocampal subfields in the mice and in resected hippocampus from patients with pharmacoresistant temporal lobe epilepsy. Cells transcribing $P 2 r x 7$ in hippocampal slices from epileptic mice displayed enhanced agonist-evoked P2X7 receptor currents, and synaptosomes from these animals showed increased P2X7 receptor levels and altered calcium responses. A $5 \mathrm{~d}$ treatment of epileptic mice with systemic injections of the centrally available, potent, and specific P2X7 receptor antagonist JNJ-47965567 (30 mg/kg) significantly reduced spontaneous seizures during continuous video-EEG monitoring that persisted beyond the time of drug presence in the brain. Hippocampal sections from JNJ-47965567-treated animals obtained $>5 \mathrm{~d}$ after treatment ceased displayed strongly reduced microgliosis and astrogliosis. The present study suggests that targeting the P2X7 receptor has anticonvulsant and possibly disease-modifying effects in experimental epilepsy.

Key words: anticonvulsant; hippocampal sclerosis; inflammatory cytokine; microglia; purinergic receptor; status epilepticus

Significance Statement

Temporal lobe epilepsy is the most common and drug-resistant form of epilepsy in adults. Neuroinflammation is implicated as a pathomechanism, but the upstream mechanisms driving gliosis and how important this is for seizures remain unclear. In our study, we show that the ATP-gated P2X7 receptor is upregulated in experimental epilepsy and resected hippocampus from epilepsy patients. Targeting the receptor with a new centrally available antagonist, JNJ-47965567, suppressed epileptic seizures well beyond the time of treatment and reduced underlying gliosis in the hippocampus. The findings suggest a potential diseasemodifying treatment for epilepsy based on targeting the P2X7 receptor.

\section{Introduction}

Temporal lobe epilepsy (TLE) is a common and often refractory brain disease characterized by recurrent seizures originating from or involving structures such as the hippocampus (Fisher et al., 2014; Moshé et al., 2015). The first-line treatment for TLE patients is with antiepileptic drugs (AEDs). These work through mechanisms including blocking sodium and calcium channels 
and promoting GABA function (Bialer and White, 2010). Current AEDs are ineffective, however, in $\sim 30 \%$ of epilepsy patients and do not alter the underlying pathophysiology. The identification of treatments for TLE with novel mechanisms of action and, ideally, disease-modifying effects would be transformational (Bialer and White, 2010; Pitkänen and Lukasiuk, 2011).

There is emerging interest in targeting gliosis and neuroinflammation as an approach to pharmacoresistant epilepsy and antiepileptogenesis (Bialer and White, 2010; Vezzani et al., 2011; Devinsky et al., 2013; Marchi et al., 2014). Astrocyte expansion and proliferation interferes with the normal reuptake of neurotransmitters and glia-neuron metabolic coupling and reduces inhibitory adenosinergic tone (Haydon and Carmignoto, 2006; Li et al., 2007; Devinsky et al., 2013). Microglia activation and proliferation can also promote hyperexcitability through neurotoxic and neuroinflammatory mechanisms (Allan et al., 2005; Block et al., 2007; Devinsky et al., 2013; Salter and Beggs, 2014). In particular, activated microglia release the cytokine interleukin- $1 \beta$ (IL-1 $\beta$ ), resulting in potentiated glutamatergic and reduced GABAergic signaling, as well as astrogliosis (Allan et al., 2005; Vezzani et al., 2011). Gene networks associated with IL- $1 \beta$ are a key molecular signature in resected hippocampi from TLE patients (Johnson et al., 2015), and targeting IL- $1 \beta$ has been reported to reduce seizures in animal models (Vezzani et al., 2010; Maroso et al., 2011).

Evidence is emerging that ATP is a key upstream trigger of neuroinflammation (Eltzschig et al., 2013; Idzko et al., 2014). ATP is released in high quantities after damage to the CNS, where it acts on plasma membrane receptors (Wang et al., 2004; Abbracchio et al., 2009; Idzko et al., 2014). The fast excitatory effects of extracellular ATP are mediated by the P2X class ionotropic receptors. The P2X7 receptor (P2X7R) has the lowest affinity for ATP and, as such, is activated mainly under conditions of pathologic release of ATP (high $\mu \mathrm{M}$-low $\mathrm{mM}$ ). The P2X7R gates depolarizing sodium and calcium entry, and triggers downstream proinflammatory signaling cascades. This includes the activation and proliferation of microglia and the formation of the inflammasome that releases IL-1 $\beta$ (Monif et al., 2009; Surprenant and North, 2009). More controversially, the P2X7R has been reported to be expressed, although at lower expression levels, by certain neurons, where it modulates neurotransmitter release (Armstrong et al., 2002; Sperlágh et al., 2002; Duan et al., 2003; Wang et al., 2004; Fellin et al., 2006; Jabs et al., 2007). Although the P2X7R has emerged as an important target in neurological disorders (Sperlágh and Illes, 2014), a role in epilepsy is unclear. The P2X7R is overexpressed in epileptic rats (Vianna et al., 2002; Rappold et al., 2006; Doná et al., 2009), and P2X7R levels are elevated in resected neocortex from TLE patients (JimenezPacheco et al., 2013). Functional studies have been limited to the

This work was supported by funding from Health Research Board Ireland (HRA-POR/2010/123, HRA-POR/2011/ 41, HRA-POR/2012/56) and Science Foundation Ireland (13/SIRG/2098, 12/COEN/18, 13/IA/1891); fellowships from the Irish Research Council (to A. J.-P.), Comunidad de Madrid (S-SAL-0253-2006 to M.T.M.-P. and A.R.A.), Spanish Ministry of Science and Education (BFU2008-02699 to M.T.M.-P.; BFU2011-26253 to A.R.A.; BFU2012-31195 to M.D.-H.), Fundación Marcelino Botín (to M.T.M.-P.), and Consolider SICI Spanish lon Channel Initiative (CSD200800005 to M.T.M.-P. and A.R.A.); and a grant from UCM-Santander Central Hispano Bank (911585-670 to M.D.-H.). We thank the University of Maryland Brain and Tissue bank for provision of the autopsy brain tissue samples, Maiken Nedergaard (University of Rochester) for granting use of the P2rx7-EGFP mice, Mairead Diviney for discussion of statistical aspects, and Heiko Dussmann for confocal support.

*T.E. and D.C.H. contributed equally to this work.

The authors declare no competing financial interests.

Correspondence should be addressed to Dr. David C. Henshall, Department of Physiology and Medical Physics, Royal College of Surgeons in Ireland, 123 St. Stephen's Green, Dublin 2, Ireland. E-mail: dhenshall@rcsi.ie.

DOI:10.1523/JNEUROSCI.4009-15.2016

Copyright $\odot 2016$ the authors $\quad 0270-6474 / 16 / 365921-13 \$ 15.00 / 0$ analysis of P2X7R antagonists, including A-438079 and brilliant blue $\mathrm{G}$ or genetic manipulation on acute chemoconvulsant responses, with mixed results (Kim and Kang, 2011; Engel et al., 2012b; Jimenez-Pacheco et al., 2013; Mesuret et al., 2014; Soni et al., 2015).

Here we investigated P2X7R expression and function in experimental and human TLE. Our hypothesis was that neurons as well as microglia express P2X7R, and that targeting the receptor would reduce hyperexcitability and gliosis in the epileptic brain. We took advantage of a reporter mouse to specifically identify the cell types expressing the receptor and tested a new centrally available P2X7R antagonist for effects on spontaneous recurrent seizures in mice.

\section{Materials and Methods}

Animal model of epilepsy. Animal experiments were performed in accordance with the principles of a European Communities Council Directive (86/609/EEC, 2010/63/EU), under licenses from the Department of Health and Health Products Regulatory Authority (Ireland), and procedures were approved by the Research Ethics Committee of the Royal College of Surgeons in Ireland. Male adult C57BL/6 mice (weight, 20-25 g; age, 6-9 weeks), were obtained from Harlan Laboratories and maintained in a vivarium with access to food and water ad libitum. P2X7R reporter mice [Tg(P2rx7-EGFP)FY174Gsat/Mmcd, stock 011959-UCD] were obtained from US National Institutes of Health Mutant Mouse Regional Resource Centers (University of Rochester, Rochester, NY). To generate these mice, an enhanced green fluorescent protein (EGFP) reporter gene, followed by a polyadenylation sequence, was inserted into BAC (bacterial artificial chromosome) clone RP181F3 at the initiating ATG codon of the first coding exon of the P2rx7 gene, so that EGFP expression is driven by the regulatory sequences of the BAC gene.

Induction of status epilepticus was performed as previously described (Engel et al., 2012b). Briefly, mice were anesthetized and placed in a stereotaxic frame. Three partial craniectomies were performed to affix cortical skull-mounted EEG electrodes (Bilaney Consultants), and EEG was recorded using a Comet XL digital EEG (Grass Technologies). A guide cannula was affixed for intra-amygdala targeting, and the skull assembly was fixed in place with dental cement. Animals were removed from the frame, allowed to recover, and then connected to the EEG. After a baseline EEG, kainic acid ( $0.3 \mu \mathrm{g}$ in $0.2 \mu \mathrm{l}$ in PBS; Sigma-Aldrich) was microinjected into the basolateral amygdala. The anticonvulsant lorazepam (6 mg/kg, i.p.; Wyeth) was administered $40 \mathrm{~min}$ later to curtail morbidity and mortality (Engel et al., 2012b).

Mice were killed at different time points up to $21 \mathrm{~d}$ after status epilepticus. All mice in this model develop recurrent spontaneous seizures within $5 \mathrm{~d}$ (Mouri et al., 2008). At the time of their death, mice were deeply anesthetized (pentobarbital) and perfused with saline to remove intravascular blood components. Brains were then either flash frozen whole in 2-methylbutane at $-30^{\circ} \mathrm{C}$ for histopathology or dissected on ice to obtain whole or microdissected hippocampus. For immunofluorescence microscopy, mice were perfused with $4 \%$ paraformaldehyde (PFA) after saline.

Brain and plasma levels of JNJ-47965567. JNJ-47965567 [N-((4-(4phenyl-piperazin-1-yl)tetrahydro-2H-pyran-4-yl)methyl)-2-(phenyl-thio) nicotinamide)] was provided by Janssen Research \& Development. To confirm that JNJ-47965567 reaches the brain after systemic administration and to assess how long brain levels remained detectable, adult mice were injected with $30 \mathrm{mg} / \mathrm{kg}$, i.p., JNJ-47965567, and killed at 15 and $30 \mathrm{~min}$ and at $1,2,4$, and $6 \mathrm{~h}$ ( $n=3$ mice/time point). Blood samples were centrifuged to isolate the plasma, and brains were frozen in dry ice, followed by compound measurement by standard analytical methods (Bhattacharya et al., 2013). We assumed that $1 \mathrm{~g}$ of brain tissue equals the weight of a $1 \mathrm{ml}$ volume of water.

Drug treatments. Animals were randomized after status epilepticus to either the treatment or vehicle group. Specifically, animal identification codes were chosen at random by one investigator, and then an independent investigator assigned the animal to receive either vehicle or drug. 
Baseline seizure frequencies were unknown to investigators at the time of assignment to treatment. Animals in the treatment group received twicedaily injections of $30 \mathrm{mg} / \mathrm{kg}$, i.p., JNJ-47965567 for $5 \mathrm{~d}$, beginning on day 11 after status epilepticus. Control animals received twice-daily injections of vehicle $(30 \% \beta$-cyclodextrin sulfobutyl ethers and sodium salt diluted in distilled water (Toronto Research Chemicals).

Epilepsy monitoring. Continuous EEG recordings in drug studies were performed using implantable EEG telemetry devices (Data Systems International; Mouri et al., 2008). Transmitters (model F20-EET, Data Sciences International) were implanted in a subcutaneous pocket at the time of the surgical procedures to equip mice for intra-amygdala kainic acid injections, and were used to record bilateral EEG from skull. Three weeks of EEG data were acquired for each animal, beginning from the time of status epilepticus until the end of the study (day 21). One animal that did not enter status epilepticus before the time of lorazepam administration was excluded from the study. Spontaneous seizures were scored blinded to treatment and defined as high-frequency $(>5 \mathrm{~Hz})$, highamplitude (more than two times baseline) polyspike discharges of $\geq 10 \mathrm{~s}$ duration that were present on both EEG channels. Seizure termination was defined as a return of EEG amplitude and frequency to baseline values with or without postictal amplitude suppression. The main parameters measured were daily seizure frequency and average seizure duration (Mouri et al., 2008; Engel et al., 2013).

To evaluate clinical behavior, up to 10 seizures per mouse were selected at random for each period (baseline, treatment, and washout), and a score was assigned. Typically, 10 seizures were analyzed per mouse in the vehicle group for each period but only $\sim 6$ seizures per mouse were scored in the JNJ-47965567 group during the on-drug and washout period due to the reduced seizure frequency. No scores could be assigned for two mice during JNJ-47965567 treatment and one mouse after JNJ47965567 washout due to the absence of any seizures. A score was attributed based on whether seizures were partial or secondarily generalized (Narkilahti et al., 2003). Briefly, partial seizures were given a score of 1 and defined as comprising one or more of the following: sudden behavioral arrest, facial automatisms, or unilateral forelimb clonus. Secondarily generalized seizures were given a score of 2 , as defined by bilateral forelimb clonus, forelimb clonus and rearing, and forelimb clonus with rearing and falling.

Histopathology and immunohistochemistry. For immunohistochemistry analyses, free-floating sections were permeabilized and blocked in goat serum followed by incubation with antibodies against GFP (1:500; Invitrogen), Iba1 (1:500; Wako Chemicals), NeuN (1:500; Merck Millipore Ireland B.V.), GFAP (1:500; Santa Cruz Biotechnology), or Synaptophysin (1:500; Sigma-Aldrich Ireland) overnight at $4^{\circ} \mathrm{C}$. Sections were washed and then incubated with goat polyclonal secondary antibodies coupled to Alexa Fluor 488 or Alexa Fluor 568 (BioSciences). To confirm specificity, additional sections were incubated without the primary antibody. Nuclei were labeled by staining with DAPI $\left(4^{\prime}, 6^{\prime}\right.$-diamidino-2phenylindole dihydrochloride; Vector Laboratories), and sections were examined under an epifluorescence microscope. Counts of $\mathrm{Iba}^{+}{ }^{+}$and $\mathrm{GFAP}^{+}$cells in the drug treatment study were performed blind to treatment. Two representative regions within a hippocampal subfield were randomly selected, and cells were counted under $40 \times$ lens magnification and averaged for each animal. Representative images of the Ibal/GFAP staining were taken using the same exposure time without knowledge of the treatment group. Confocal images were acquired with a Leica TCR 6500 microscope equipped with four laser lines $(405,488,561$, and 653 $\mathrm{nm}$ ) using a $63 \times$ immersion oil objective.

RNA extraction and real-time quantitative PCR. RNA extraction was undertaken as previously described using TRIzol (QIAzol Lysis Reagent, Qiagen; Engel et al., 2013). Briefly, $1 \mu \mathrm{g}$ of total RNA was used to generate cDNA by reverse transcription using SuperScript II reverse transcriptase enzyme (Invitrogen). Quantitative real-time PCR was performed using a LightCycler 2.0 (Roche Diagnostics) in combination with QuantiTect SYBR Green PCR kit (Qiagen) as per the manufacturer protocol, and with $1.25 \mu \mathrm{M}$ custom-designed pair primers (Primer 3.0, Sigma-Aldrich) for the selected target genes. Data were analyzed by LightCycler 2.0 software, normalized to the expression of $\beta$-actin and represented as relative quantification values. Primers were designed using Primer3 software
Table 1. Autopsy control details

\begin{tabular}{lllllc}
\hline Donor & Sex & Age (years) & Tissue & Cause of death & PMI (h) \\
\hline C1 & F & 35 & Hippocampus & Multiple injuries & 2 \\
C2 & F & 24 & Hippocampus & Head injuries & 7 \\
C3 & F & 42 & Hippocampus & HASCVD & 4 \\
C4 & M & 32 & Hippocampus & Morphine intoxication & 7 \\
C5 & M & 41 & Hippocampus & Mixed drug intoxication & 6 \\
C6 & M & 29 & Hippocampus & Acute pancreatitis & 8 \\
C7 & M & 40 & Hippocampus & Hemopericardium & 9 \\
C8 & M & 39 & Hippocampus & Hemopericardium & 16 \\
C9 & M & 50 & Hippocampus & Acute alcohol intoxication & 19 \\
C10 & F & 46 & Hippocampus & HASCVD & 18 \\
C11 & F & 37 & Hippocampus & Asthma & 16 \\
C12 & F & 42 & Hippocampus & Cardiac arrhythmia & 12 \\
\hline
\end{tabular}

F, Female; HASCVD, hypertensive arteriosclerotic cardiovascular disease; M, male; PMI, postmortem interval.

(http://frodo.wi.mit.edu) and were verified by BLAST (http://blast.ncbi. nlm.nih.gov/Blast.cgi). Primer sequences were as follows: $\beta$-actin: forward, $5^{\prime}$-gggtgtgatggtgggaatgg- $3^{\prime}$; reverse, $3^{\prime}$-ggttggccttagggttcagg- $5^{\prime}$; P2rx2: forward $5^{\prime}$-atgggattcgaattgacgtt- $3^{\prime}$; reverse, $3^{\prime}$-gatggtgggaatgagactgaa- $5^{\prime}$; and P2rx7: forward, $5^{\prime}$-ctggcaggtgtgttccata- $3^{\prime}$; reverse $3^{\prime}$-ttggcaagatgtttctcgtg-5'.

Western blot analysis. Western blotting was performed as previously described (Engel et al., 2012b). Proteins were extracted from human or mouse hippocampus, separated by SDS-PAGE, transferred to nitrocellulose membranes, and then immunoblotted with the following primary antibodies: P2X2R and P2X7R (APR-004, APR-003; 1:500; Alomone Labs), Synaptophysin (1:200; Sigma-Aldrich), GAPDH (1:1000; Cell Signaling Technology), and $\beta$-actin and $\alpha$-tubulin (1:1000; Sigma-Aldrich). The specificity of the P2X receptor antibodies was confirmed by preabsorbing with the P2X7R peptide antigen or a peptide antigen against the P2X4R (Alomone Labs). Horseradish peroxidase-conjugated goat antirabbit or anti-mouse antibodies (dilution, 1:5000; Millipore) were then applied and used as secondary antibodies. Protein bands were visualized using SuperSignal West Pico Chemiluminescent Substrate (Pierce). Gel band image densities were captured using a Fujifilm LAS-4000 imaging system and analyzed using Alpha-EaseFC 4.0 software.

Human brain tissue samples. This study was approved by the Ethics (Medical Research) Committee of Beaumont Hospital, Dublin (05/18), and written informed consent was obtained from all patients. Patients $(n=12)$ were referred for surgical resection of the temporal lobe for the treatment of intractable TLE. After temporal lobe resection, the hippocampus was divided, with one piece frozen in liquid nitrogen and stored at $-80^{\circ} \mathrm{C}$. The remaining bloc was processed for routine pathological analysis, and samples were assessed for the presence of hippocampal sclerosis and other pathological changes. Control (autopsy) hippocampi $(n=12)$ were obtained from 12 individuals with no history of neurological disease from the University of Maryland Brain and Tissue Bank (Baltimore, MD). Groups were balanced for sex ( 6 males $/ 6$ females ratio for both groups) and age (control group: average age, 38 years (age range, $24-50$ years); TLE group: average age, 37 years (age range, $18-49$ years) ]. The average postmortem interval was $6.5 \mathrm{~h}$. Full details of control subject and patient pathology and clinical data can be found in Tables 1 and 2.

Synaptosome preparation. Synaptosomes were prepared as reported with modifications (Díaz-Hernández et al., 2001a). Three independent samples, each comprising pools of two ipsilateral hippocampi, were prepared from control and epileptic mice (14 d post-status epilepticus). Tissue was homogenized with $300 \mu \mathrm{l}$ of sucrose-TES buffer [ $0.25 \mathrm{M}$ sucrose; 5 mM TES (2-\{[1,3-dihydroxy-2-(hydroxymethyl)-2-propanyl] amino\} ethanesulfonic acid), pH 7.4] on ice using a glass-Teflon douncer with seven strokes at $700 \mathrm{rpm}$. Volume was adjusted using sucrose-TES buffer, and the homogenized sample was centrifuged at $2000 \times g$ for 3 $\min$ at $4^{\circ} \mathrm{C}$. The supernatant was recovered and then spun again at $9500 \times g$ for $13 \mathrm{~min}$ at $4^{\circ} \mathrm{C}$. Then, the supernatant was discarded, and the pellet containing the synaptosomes resuspended in $2 \mathrm{ml}$ of sucrose-TES buffer and subsequently placed in the top of a Percoll gradient $(3 \%, 10 \%$, and $23 \%$ ). Each sample was centrifuged at $25,000 \times g$ for $11 \mathrm{~min}$ at $4^{\circ} \mathrm{C}$. 
Table 2. TLE patient clinical and pathological details

\begin{tabular}{|c|c|c|c|c|}
\hline Patient & Sex & Age (years) & Tissue & Diagnosis and other pathology findings \\
\hline E1 & M & 30 & Hippocampus & Hippocampal sclerosis, dysembryoplastic neuroepithelial tumor, probable microscopic involving temporal stem \\
\hline E2 & $\mathrm{F}$ & 33 & Hippocampus & Hippocampectomy: mesial temporal sclerosis \\
\hline E3 & $\mathrm{F}$ & 49 & Hippocampus & Hippocampal sclerosis \\
\hline E4 & $\mathrm{F}$ & 40 & Hippocampus & Hippocampal sclerosis \\
\hline E5 & M & 43 & Hippocampus & Hippocampus: gliosis \\
\hline E6 & M & 46 & Hippocampus & Minimal hippo gliosis \\
\hline E7 & $\mathrm{F}$ & 18 & Hippocampus & Hippocampus: mesial temporal sclerosis \\
\hline E8 & M & 19 & Hippocampus & Temporal stem hemosiderin deposition; no evidence of neoplasia or of hippocampal sclerosis \\
\hline E9 & M & 40 & Hippocampus & Hippocampus astrocytosis: no evidence of inflammation or neoplasia \\
\hline E10 & $\mathrm{F}$ & 38 & Hippocampus & Mesial temporal sclerosis \\
\hline E11 & $\mathrm{F}$ & 33 & Hippocampus & Hippocampus neuronal loss, dentate fascia, and gliosis \\
\hline $\mathrm{E} 12$ & $\mathrm{~F}$ & 54 & Hippocampus & Mesial temporal sclerosis \\
\hline
\end{tabular}

F, Female; $M$, male.

The fraction left between the $10 \%$ and $23 \%$ layers (the synaptosomes) was extracted and diluted in $15 \mathrm{ml}$ of HEPES-buffered medium (HBM)-no $\mathrm{Ca}^{2+}$ buffer [140 mM NaCl, $5 \mathrm{~mm} \mathrm{KCl,} 5$ mM NaHCO $3,1.2$

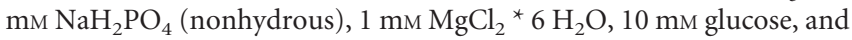
$10 \mathrm{~mm}$ HEPES]. The suspension was spun at $20,000 \times \mathrm{g}$ for $11 \mathrm{~min}$ at $4^{\circ} \mathrm{C}$, and the pellet was resuspended in $\mathrm{HBM}+\mathrm{Ca}^{2+}$ buffer. Last, $200 \mu \mathrm{l}$ of synaptosomes was gently dropped onto coverslips pretreated with polyL-lysine and laminin (Life Technologies). The coverslips containing $\sim 700$ synaptosomes were then placed in a calcium-sensitive fluorescent indicator (FURA- 2AM, Invitrogen) for calcium microfluorimetric analysis or fixed in 4\% PFA for immunostaining.

Calcium microfluorimetric analysis. Free intracellular calcium concentrations $\left(\left[\mathrm{Ca}^{2+}\right]_{\mathrm{i}}\right)$ were monitored using the calcium sensitive fluorescent indicator FURA-2AM $(5 \mu \mathrm{M})$, as previously described (Díaz-Hernández et al., 2001b). Synaptosomes were incubated in HBM solution containing FURA2-AM for $40 \mathrm{~min}$ at $37^{\circ} \mathrm{C}$ and subsequently placed in a superfusion chamber (Warner Instruments) attached to an epifluorescence microscope (Leica Microsystems). The $\mathrm{Ca}^{2+}$ indicator was excited through a $100 \times$ fluorine objective (TE200; Nikon) with $510 \mathrm{~nm}$ light via an optical quartz guide. Fluorescence signals were collected at $340-380 \mathrm{~nm}$, and ratios were determined at $1 \mathrm{~s}$ intervals. $\left[\mathrm{Ca}^{2+}\right]_{\mathrm{i}}$ responses to the P2X7R agonist BzATP (30 $\mu \mathrm{M}, 30 \mathrm{~s}$; Sigma-Aldrich) were recorded over $1 \mathrm{~min}$, and 2 min after a pulse of high $\mathrm{K}^{+}(100 \mathrm{~mm}, 30 \mathrm{~s})$ was applied as a positive control. Basal fluorescence was determined before the first application of BzATP. To assess the proportion of synaptosomes responding to BzATP, we set at $100 \%$ the total number of synaptosomes responding to $\mathrm{K}^{+}$, and then compared the percentage of those that responded to BzATP. Fluorescence was imaged for each region of interest and analyzed using MetaFluor Fluorescence Ratio Imaging Software (Molecular Devices). Data are represented as the normalized fluorescence ratio $\mathrm{F} 340 / \mathrm{F} 380$, which increases when $\left[\mathrm{Ca}^{2+}\right]_{\mathrm{i}}$ rises.

Synaptosome preparation for Western blotting. Mouse hippocampi were dissected on ice, and the tissue was homogenized in $10 \mathrm{ml}$ of ice-cold homogenizing buffer ( $0.32 \mathrm{~m}$ sucrose, $1 \mathrm{~mm}$ EDTA, $1 \mathrm{mg} / \mathrm{ml}$ bovine serum albumin, and 5 mM HEPES, pH 7.4) in a glass-Teflon douncer with $\sim 10$ strokes at $4^{\circ} \mathrm{C}$. Next, samples were centrifuged for $10 \mathrm{~min}$ at $3000 \times \mathrm{g}$ at $4^{\circ} \mathrm{C}$, and the supernatant recovered (cytoplasm and synaptosomes). Samples were again centrifuged for $12 \mathrm{~min}$ at $14,000 \times g$ at $4^{\circ} \mathrm{C}$, and the supernatant was discarded. Pelleted synaptosomes were resuspended in $550 \mu \mathrm{l}$ of Krebs-Ringer buffer (140 mM NaCl, $5 \mathrm{~mm} \mathrm{KCl}, 5 \mathrm{~mm}$ glucose, 1 mm EDTA, and 10 mm HEPES, $\mathrm{pH}$ 7.4). Then, $450 \mu \mathrm{l}$ of Percoll ( $45 \% \mathrm{v} / \mathrm{v})$ was added, and the two components were mixed by gently inverting the tube. After a $2 \mathrm{~min}$ spin at $14,000 \times g$ at $4^{\circ} \mathrm{C}$, enriched synaptosomes were recovered and resuspended in $1 \mathrm{ml}$ of Krebs-Ringer buffer. Samples were again spun for $30 \mathrm{~s}$ at $14,000 \times g$, and the supernatant was discarded. The pellet containing the synaptosomes was resuspended in assay buffer (HEPES-Krebs buffer) and stored at $-20^{\circ} \mathrm{C}$.

Electrophysiological recordings. Brains were extracted from P2rx7EGFP mice $14 \mathrm{~d}$ after status epilepticus and quickly sectioned through the sagittal plane. Brain slices (300 $\mu \mathrm{m}$ thickness) were then attached to an agarose cube using cyanoacrylate glue and placed on the stage of a vibratome cuvette (Integraslice 7550, Campden Instruments) filled with a saline solution $\left(125 \mathrm{~mm} \mathrm{NaCl}, 2.5 \mathrm{~mm} \mathrm{KCl}, 1 \mathrm{mM} \mathrm{CaCl}_{2}, 1.25\right.$ mм $\mathrm{NaH}_{2} \mathrm{PO}_{4}, 26 \mathrm{~mm} \mathrm{NaHCO}_{3}$, and $12 \mathrm{~mm}$ glucose, $\mathrm{pH} 7.4, \sim 300$ $\mathrm{mOsm})$ at $4^{\circ} \mathrm{C}$. Brain slices were kept in saline solution continuously bubbled with carbogen $\left(95 \% \mathrm{O}_{2} / 5 \% \mathrm{CO}_{2}\right)$ at room temperature (RT) for a maximum of $6 \mathrm{~h}$ before being transferred to the recording chamber. This was attached to the stage of an upright microscope (BX51W1, Olympus) and connected to a gravity-driven perfusion pump system, which delivered the above-mentioned saline solution at a rate of $2 \mathrm{ml} / \mathrm{min}$ at RT. A $63 \times$ water-immersion objective and a DL-604 OEM camera (Andor Technology) were used for the EGFP cell visualization in the dentate gyrus (DG) and CA1 regions of the hippocampus. Electrophysiological recordings were performed with an EPC10/2 patch-clamp amplifier using PatchMaster software (HEKA Electronic). Patch pipettes were fabricated from borosilicate capillaries (Kimble Chase) with a Narishige PP830 puller to a final resistance of 5-6 M $\Omega$ when filled with the intracellular solution [140 $\mathrm{mm}, \mathrm{N}$-methyl-D-glucamine $\left(\mathrm{NMDG}^{+}\right.$), $5 \mathrm{~mm}$ EGTA, $3 \mathrm{~mm} \mathrm{MgCl}_{2}$, $10 \mathrm{~mm}$ HEPES, pH 7.2, adjusted with $\mathrm{HCl}, \sim 290 \mathrm{mOsm}]$. Whole-cell currents measured at a holding voltage $\left(\mathrm{V}_{\mathrm{h}}\right)$ of $-70 \mathrm{mV}$ were filtered at $3 \mathrm{kHz}$ and sampled at $10 \mathrm{kHz}$. Series resistance was compensated by $80 \%$ and monitored throughout the experiment together with the cell membrane capacitance. Considering an average series resistance of 10 $\mathrm{M} \Omega$, a neuron membrane capacitance of $7.06 \pm 0.9 \mathrm{pF}$ ( $n=22$ cells), and the molecular weight of $\mathrm{NMDG}^{+}(195.21 \mathrm{kDa})$, we estimated in $\sim 10$ min the time needed for $\mathrm{NMDG}^{+}$to equilibrate between the patch pipette and the cytoplasm of the recorded cell (Pusch and Neher, 1988). Drug applications therefore began 10 min after obtaining the whole-cell configuration. Likewise, experiments in which series resistance changed by $>20 \%$ or in which holding current exceeded 20 pA were not analyzed. BzATP $(100 \mu \mathrm{M})$ was applied onto the recorded cell by means of separated glass pipettes (3-5 $\mu \mathrm{m}$ tip diameter) connected to a pneumatic drug ejection system (PDES-02DX, npi). At variance, the P2X7R antagonist A438079 (10 $\mu \mathrm{M}$; Sigma-Aldrich) was administered through the perfusate 2 min before and during BzATP application.

Data analysis. Data are presented as the mean \pm SEM. Two-group comparisons were analyzed using Student's $t$ test and Mann-Whitney $(\mathrm{M}-\mathrm{W})$ test for nonparametric data. Multi-subfield comparisons of gene expression data (mRNA, protein), electrophysiological data, and glial histopathology were analyzed by ANOVA with post hoc Bonferroni test (parametric) or Dunn's test (nonparametric) to correct for repeated measures (Prism version 6, GraphPad). Statistical analysis of the drug treatment study was performed by calculating the Mann-Whitney statistic (also known as Harrell's c) using Newson's command somersd (Newson, 2006a,b). Calculations were adjusted for clustering within animals using the Stata robust variance estimates. Hypothesis tests compared the observed value of the Mann-Whitney statistic to the null value (0.5). Additional statistical analysis of the effect of JNJ-47965567 on spontaneous seizures was performed using Stata and are included in the Results section. Significance was accepted at $p<0.05$. 
A
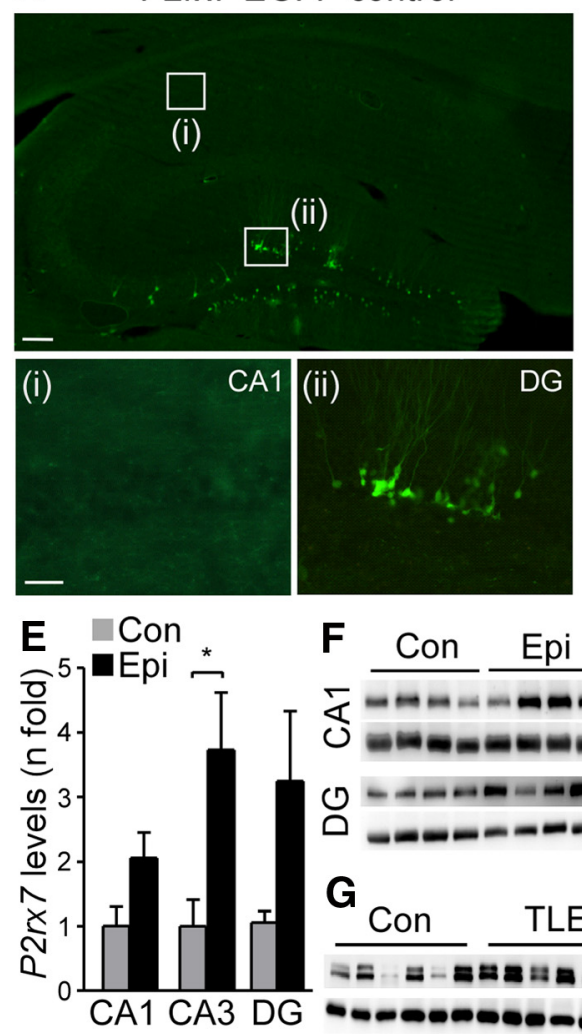

F

G

Con

TLE
B
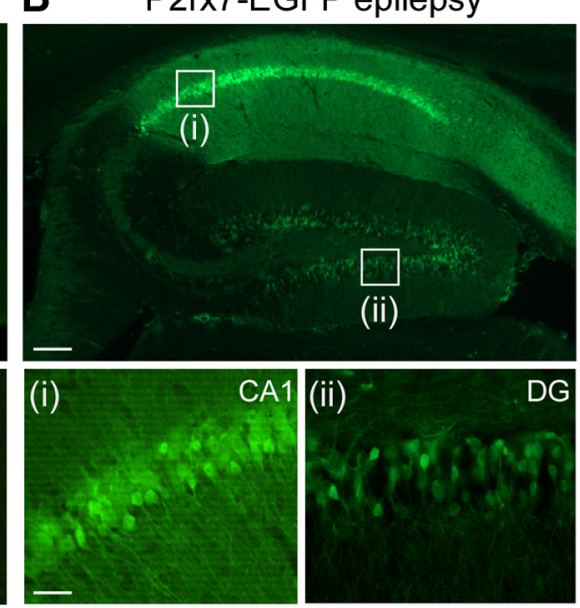

C Neun GFP

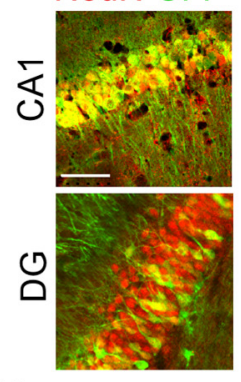

D

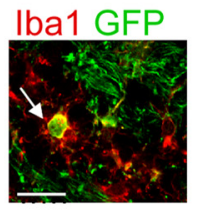

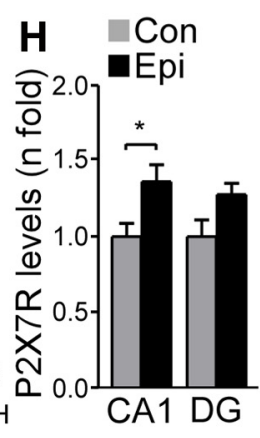

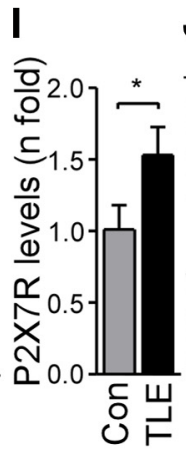

$\mathbf{J}_{\text {Mouse }}$

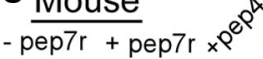

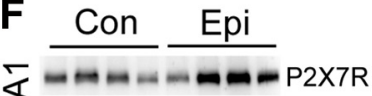

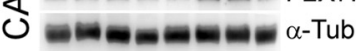

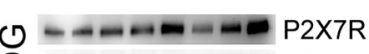

(1)

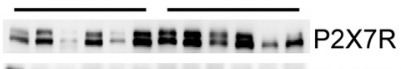

GAPDH

Figure 1. Increased expression of P2X7R in experimental and human epilepsy. A, Photomicrograph showing EGFP immunofluorescence in the hippocampus of a control P2rx7-EGFP mouse. Scale bar, $125 \mu \mathrm{m}$. Panels below show higher-power images of CA1 (i) and DG (ii) hippocampal subfields from the P2rx7-EGFP control animal. Scale bar, $50 \mu \mathrm{m}$. Note that the constitutive EGFP appears mainly in cells of the DG. $\boldsymbol{B}$, Photomicrograph showing EGFP immunofluorescence in the hippocampus of an epileptic P2rx7-EGFP mouse $14 \mathrm{~d}$ after status epilepticus. Scale bar, $125 \mu \mathrm{m}$. Panels below show higher-power images of CA1 (i) and DG (ii) hippocampal subfields from the P2rx7-EGFP epileptic animal. Scale bar, $50 \mu \mathrm{m}$. C, Double-stained confocal immunofluorescence images showing EGFP (green, GFP) and neuronal marker NeuN (red), in the CA1 and DG subfields from epileptic P2rx7-EGFP mice. Scale bar, $50 \mu \mathrm{m}$. D, Immunofluorescence staining showing EGFP (green, GFP) and microglia marker Iba1 (red) in the CA3 subfield of a P2rx7-EGFP epileptic mouse. Scale bar, $20 \mu \mathrm{m}$. Images are representative of data from $n=5$ animals per group. $\boldsymbol{E}$, Graph showing $P 2 r \times 7 \mathrm{mRNA}$ levels in the CA1, CA3, and DG subfields of control (Con) and epileptic (Epi) mice ( $n=9$ /group; ANOVA with Bonferroni test, $\left.{ }^{*} p<0.05\right)$. $\boldsymbol{F}$, Representative Western blots ( $n=1 /$ /lane) showing P2X7R protein ( $\sim 70 \mathrm{kDa}$ ) within the CA1 and DG subfields in vehicle-injected control and epileptic mice. $\alpha$-Tubulin is shown as a guide to loading. G, Representative Western blot $(n=1 /$ lane) showing P2X7R protein in the hippocampus of human control and TLE patients. GAPDH is shown as a guide to loading. $\boldsymbol{H}$, Graph showing P2X7R protein levels in CA1 and DG subfields in vehicle-injected control and epileptic animals ( $n=9 /$ group; ANOVA with Bonferroni test, ${ }^{*} p<0.05$ ). $I$, Graph showing P2X7R protein levels in the hippocampus of TLE patients when compared with controls ( $n=$ 12/group; Student's $t$ test, ${ }^{*} p<0.05$ ). J, Antibody preabsorption test. Western blots show a P2X7R band (left panels) in epileptic mouse and human hippocampal samples ( $n=1 /$ lane) and elimination of the band (middle panels) when the antibody was preincubated with the antigen peptide for the P2X7R (+ pep7r). Right panels show the band remains when antibodies were preincubated with the peptide antigen for P2X4R (+ pep4r).

\section{Results}

Cell-specific increase in P2X7R expression in the epileptic mouse hippocampus

We first sought to define the cell types that express the P2X7R in an animal model of acquired TLE. Although there is little argument that microglia express the P2X7R, it is controversial whether the receptor is present on neurons or astrocytes (Anderson and Nedergaard, 2006; Sperlágh and Illes, 2014). Resolving this issue may help to explain the mechanisms by which the P2X7R modulates neuroinflammation and hyperexcitability. To avoid the limitations of P2X7R antibody-based immunohistochemistry approaches (Sim et al., 2004; Anderson and Nedergaard, 2006), we used a reporter mouse in which transcription of the P2X7R also drives EGFP to enable the precise identification of cells transcribing the receptor (Engel et al., 2012a; JimenezPacheco et al., 2013). Epilepsy was induced in these mice by intraamygdala microinjection of kainic acid (Mouri et al., 2008; Engel et al., 2012b). This produces status epilepticus and subsequent damage to the ipsilateral CA3 subfield, along with some limited injury to the CA1 and DG/hilar region. All mice develop recurrent spontaneous seizures within $5 \mathrm{~d}$ (Mouri et al., 2008).

Confocal microscopic analysis of hippocampal sections identified scattered $\mathrm{EGFP}^{+}$cells in control P2rx7-EGFP mice (Fig. $1 A$ ), consistent with previous reports (Engel et al., 2012a). These were mainly in the DG cell layer as well as occasionally present in the CA3 subfield. $\mathrm{EGFP}^{+}$cells had a mainly neuronal appearance, although microglia-like $\mathrm{EGFP}^{+}$cells were also observed (Fig. $1 A$ ). $\mathrm{EGFP}^{+}$cells were not normally found in the CA1 subfield (Fig. 1A).

Analysis of sections from the ipsilateral hippocampus of P2rx7-EGFP mice 2 weeks after status epilepticus, when animals had active epilepsy, detected dramatically increased EGFP staining (Fig. 1B). Numbers of EGFP ${ }^{+}$cells were most increased in the CA1 subfield, often continuously along the length of the pyramidal cell layer (Fig. $1 B$ ). This pattern was not present in the CA1 subfield in the contralateral hippocampus of epileptic P2rx7EGFP mice (data not shown). Increased numbers of EGFP ${ }^{+}$cells were also found in the granule cell layer of the DG (Fig. 1B). 
Within the CA3 lesion site, where neuron loss was extensive, there were only occasional EGFP ${ }^{+}$cells (data not shown).

Counterstaining hippocampal sections from epileptic P2rx7EGFP reporter mice with antibodies against NeuN determined that the majority of $\mathrm{EGFP}^{+}$cells in both the CA1 subfield and DG were neurons (Fig. 1C). In the ipsilateral CA3 lesion area, there were only a few $\mathrm{NeuN}^{+}$cells remaining in epileptic mice, and these were typically $\mathrm{EGFP}^{-}$(data not shown).

EGFP $^{+}$cells were also found in each hippocampal subfield, including CA3, that stained for Iba1, indicating that a population of cells expressing the P2rx7 were microglia (Fig. 1D; data not shown). We did not detect any $\mathrm{EGFP}^{+}$cells that labeled for the astrocyte marker GFAP (data not shown).

\section{P2X7R upregulation in experimental and human epilepsy}

To extend the reporter mouse data, we performed real-time quantitative PCR analysis of P2rx7 transcript levels in the hippocampus of wild-type C57BL/6 epileptic mice. P2rx7 mRNA levels were increased in the ipsilateral hippocampus from mice $14 \mathrm{~d}$ after status epilepticus (Fig. 1E). As a control, we assessed levels of $P 2 r x 2$, another member of the P2X receptor family reported to be regulated in the short term after status epilepticus (Engel et al., 2012b). P2rx2 mRNA levels were unchanged in all three ipsilateral hippocampal subfields (data not shown).

We next assessed protein levels of the receptor by Western blot analysis. A band corresponding to the predicted weight of P2X7R was detected at $\sim 70 \mathrm{kDa}$ in control samples (Fig. 1F). P2X7R protein levels were increased within the CA1 subfield of epileptic mice (Fig. $1 F, H$ ) but were similar to controls in the DG and CA3 subfields (Fig. $1 F, H$; data not shown). There were no differences in $\mathrm{P} 2 \mathrm{X} 2 \mathrm{R}$ protein levels between control and epilepsy samples in any subfield (data not shown).

To explore the clinical relevance of these findings, we analyzed P2X7R protein levels in a set of surgically resected hippocampi from TLE patients and compared them with those of autopsy control subjects (Tables 1,2). Western blot analysis determined that P2X7R protein levels were higher in TLE patient samples compared with those of control subjects (Fig. 1G,I). P2X2R levels in TLE patients were similar to those in control subjects (data not shown). A simulated autopsy delay using mouse brain determined that the higher P2X7R levels in TLE samples were not due to an effect of postmortem interval (data not shown). As a confirmation of antibody specificity and since a double band was observed in samples, perhaps a result of splice variants or posttranslational modifications (Sperlágh and Illes, 2014), we performed preabsorption tests. The $\mathrm{P} 2 \mathrm{X} 7 \mathrm{R}$ protein band was eliminated when epileptic mouse or human samples were preabsorbed with the control peptide antigen for P2X7R, but not another P2X peptide antigen (Fig. 1J). Together, these results confirm that P2X7R upregulation is a feature of the pathophysiology of the hippocampus in experimental and human epilepsy.

\section{Increased P2X7R functional responses in experimental epilepsy}

It is unknown whether P2X7R-gated functional responses are altered in epileptic tissue. We hypothesized that the increased P2X7R expression in epilepsy would be associated with increased cellular responses to activation of the receptor. To test this idea, we performed patch-clamp recordings of agonist-evoked inward currents in hippocampal slices. For these experiments, we again used epileptic P2rx7-EGFP mice to enable us to distinguish P2rx7-expressing cells from adjacent cells not transcribing the receptor. The neuronal subtype of the recorded cells (granule neurons, interneurons, or otherwise) was not determined.

Application of the P2X7R agonist BzATP produced minimal responses in recordings from $\mathrm{EGFP}^{-}$cells in the DG (Fig. 2A-C). In contrast, the application of BzATP to DG cells expressing EGFP resulted in a rapid inward current into cells from the same animal (Fig. $2 A-C$ ). There was a significant main effect of group $\left(F_{(1,23)}=10.5 ; p<0.05\right)$; post hoc analysis showed that BzATPevoked currents were significantly larger in the $\mathrm{EGFP}^{+}$cells during the first and the second pulse than in the non- $\mathrm{EGFP}^{+}$cells. Similar results were obtained in patch-clamp recordings from cells in the CA1 subfield (Fig. $2 A-C$ ). There was a significant main effect of group $\left(F_{(1,26)}=36.52 ; p<0.005\right)$; post hoc analysis showed that BzATP-evoked currents were significantly larger in the $\mathrm{EGFP}^{+}$cells during the first, second, and third pulse than in the non-EGFP ${ }^{+}$cells.

To confirm that this was specific to the P2X7R, experiments were repeated in the presence of a bath-applied P2X7R antagonist (Fig. 2D). Agonist-evoked currents in $\mathrm{EGFP}^{+}$cells in both the DG and the CA1 subfield were blocked by the P2X7R antagonist A-438079 (Fig. 2D). These data confirm that functional P2X7Rgated responses are present in hippocampal cells from epileptic mice expressing the receptor.

The P2X7R has been reported to localize to presynaptic sites in the hippocampus where it may contribute to neurotransmitter release (Armstrong et al., 2002; Sperlágh et al., 2002). To determine whether this localization was changed in epilepsy, we prepared synaptosomes from control and epileptic mice, and stained them with specific P2X7R antibodies. Preabsorption of the antibodies with the antigen peptide eliminated staining (data not shown). In synaptosomes from control mice, there was moderate overlap of P2X7R immunoreactivity with the synaptic marker synaptophysin (Fig. 2E). In sections from epileptic mice, this colocalization was more prominent, consistent with increased synaptic P2X7R localization (Fig. 2E). These findings were supported by Western blot analysis of P2X7R levels in synaptosomes, in which higher levels of $\mathrm{P} 2 \mathrm{X} 7 \mathrm{R}$ protein were found in epileptic compared with nonepileptic mice (Fig. $2 F$ ).

Last, we sought to determine whether the increased synaptic P2X7R had functional effects on responses to agonist application. Synaptosomes were prepared from control or epileptic mice, and agonist-evoked intracellular calcium changes were recorded (Fig. $2 G, H)$. Overall, a greater proportion of synaptosomes responded to BzATP application with a calcium response in epileptic mice compared with control mice (Fig. 2G). In synaptosomes from control mice, BzATP application resulted in a rapid and shortlasting increase in $\left[\mathrm{Ca}^{2+}\right]_{\mathrm{i}}$ (Fig. $2 \mathrm{H}$ ). In synaptosomes from epileptic mice, BzATP application produced a similar initial calcium response, but was also frequently accompanied by additional intracellular calcium spikes that continued after agonist application (Fig. 2H,I). Together, these findings suggest that there is increased synaptically localized P2X7R in epilepsy and that functional responses may be enhanced or aberrant.

\section{Treatment of mice with a P2X7R antagonist produces lasting suppression of epileptic seizures}

To test whether targeting the P2X7R has an effect on spontaneous seizures, we sought a P2X7R antagonist that is centrally available after systemic injection to treat epileptic mice. In previous work, we performed intracerebral injections of A-438079 to study the effect of P2X7R inhibition on status epilepticus (Engel et al., 2012b; Jimenez-Pacheco et al., 2013). However, recent work in rodents revealed that A-438079 has poor CNS penetration fol- 
A

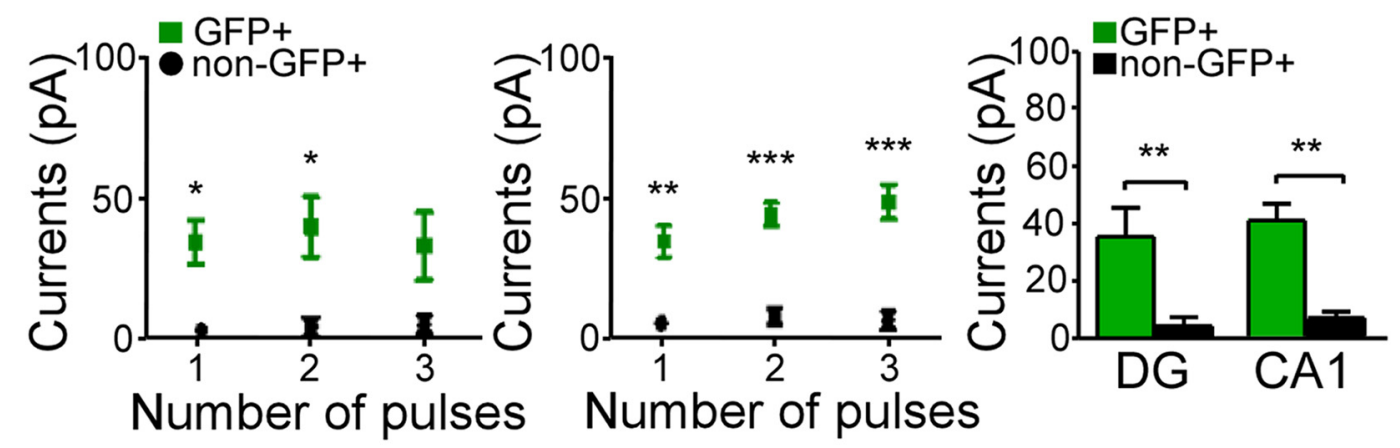

CA1 B

C
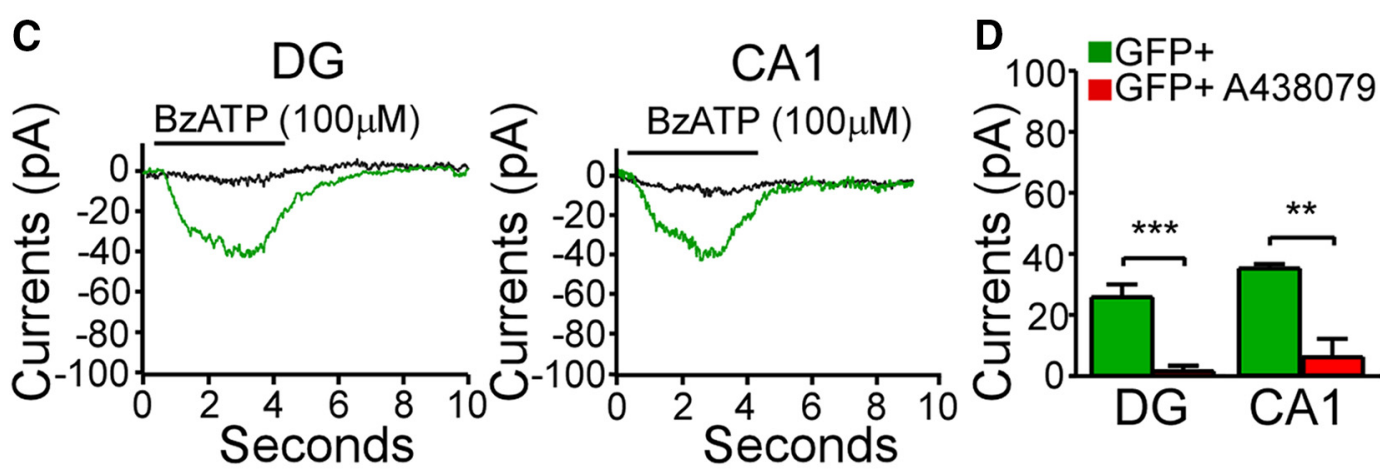

E
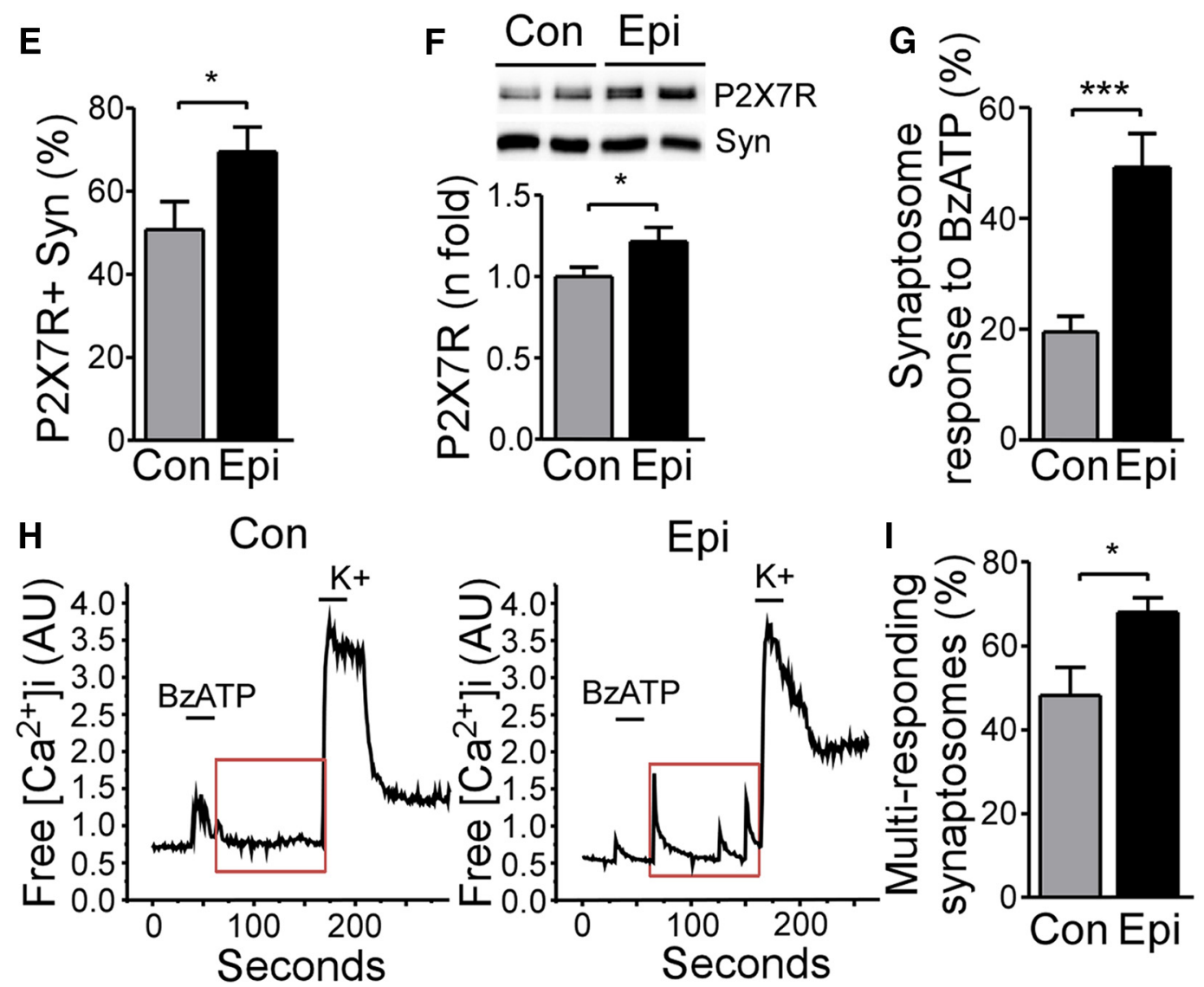

Figure 2. Increased functional responses of P2X7R to agonist stimulation in epilepsy. $A, B$, Increased current responses of EGFP ${ }^{+}$cells when compared with non-EGFP ${ }^{+}$cells from the same animal in DG and CA1 hippocampal subfields to the P2X7R agonist BZATP $(100 \mu \mathrm{M})$ during patch-clamp recordings in hippocampal slices from P2rx7-EGFP epileptic mice $\left[n=10\right.$ (EGFP $\left.{ }^{+}, \mathrm{DG}\right), n=$ $4\left(\right.$ EGFP $\left.^{+}, \mathrm{CA1}\right), n=4$ (non-EGFP $\left.{ }^{+}, \mathrm{DG}\right)$, and $n=5$ (non-EGFP ${ }^{+}$CA1). Data in $\boldsymbol{A}$ and summary data in $\boldsymbol{B}$, ANOVA with Bonferroni test, ${ }^{*} p<0.05,{ }^{* *} p<0.01,{ }^{* * *} p<0.001$ compared with non-EGFP group. C, Representative traces showing increased inwardly directed nonsensitizing currents evoked by BzATP $(100 \mu \mathrm{M})$ from EGFP ${ }^{+}$cells (green lines) when compared with non-EGFP ${ }^{+}$ cells (black lines) in epileptic EGFP-P2rx7 mice. Horizontal lines represent the time of BzATP application. D, Graph showing significantly suppressed responses to $100 \mu \mathrm{m}$ BzATP in EGFP ${ }^{+}$cells in the presence of the specific P2X7R antagonist A438079 $(10 \mu \mathrm{M})$ in brain slices from epileptic P2rX7-EGFP mice ( $n=3 /$ group). ANOVA with Bonferroni test, ${ }^{* *} p<0.01,{ }^{* * *} p<0.001 . E$, Graph showing the percentage of P2X7R ${ }^{+}$synaptosomes in hippocampal samples from control (Con) and epileptic (Epi) mice ( $n=3 /$ group). F, Representative Western blot (Figure legend continues.) 
lowing systemic administration and is rapidly eliminated from the brain (Bhattacharya et al., 2013; Mesuret et al., 2014). We therefore selected JNJ-47965567, a recently described potent and specific antagonist of the P2X7R that is centrally available after systemic injection in rodents (Bhattacharya et al., 2013).

We first confirmed that JNJ-47965567 reaches the brain after systemic injection in naive (nonepileptic) mice (Fig. $3 A$ ). Intraperitoneal injection of mice with JNJ-47965567 (30 mg/kg) resulted in a rapid increase, with high levels of the drug in both plasma and brain (Fig. 3A). High plasma and brain levels of JNJ47965567 were also detected in mice killed $2 \mathrm{~h}$ after injection. In mice killed 4-6 h after injection, levels had fallen back toward baseline levels (Fig. 3A; data not shown). Thus, systemic injections of JNJ-47965567 are well suited for achieving the necessary sustained brain levels for the planned studies.

Figure $3 B$ shows the experimental design used to assess the effects of JNJ-47965567 and the distribution of spontaneous seizures over time for the two groups. Mice were equipped with EEG telemetry units and were subjected to status epilepticus induced by intra-amygdala kainic acid. Video-EEG monitoring commenced immediately, and the freely moving mice were recorded continuously for the next 3 weeks. Ten days after status epilepticus, all mice were epileptic and displayed frequent spontaneous seizures, as previously reported (Mouri et al., 2008). Mice were then assigned in a random, blinded manner to receive either vehicle or JNJ-47965567, starting on day 11. While undergoing treatment, mice received twice-daily injections of drug or vehicle for $5 \mathrm{~d}$. Treatment was then discontinued, and mice were recorded for the next $6 \mathrm{~d}$. This additional recording time enabled us to assess seizure frequency after washout of the drug and to address any potential disease-modifying effect of JNJ-47965567.

Before commencing drug treatment, both groups of mice were experiencing frequent spontaneous seizures, which is consistent with previous reports in this model (Fig. $3 B, C$ ). There were no differences in spontaneous seizure frequency between groups before treatment ( $\mathrm{M}-\mathrm{W}$ statistic is $0.49, p=0.844$, corrected for clustering of observations with animals; Fig. $3 C$ ).

During treatment, spontaneous seizure rates declined in mice injected with JNJ-47965567 compared with mice injected with vehicle, and this reached statistical significance $(p=0.043$; M-W statistic $=0.36$, meaning that there was a $64 \%$ probability of there being fewer seizures in an animal injected with JNJ-47965567 than in an animal injected with vehicle during the drug phase; Fig. 3C).

During the washout period, spontaneous seizure rates in vehicle-treated mice continued at a similar rate of approximately six per day. In contrast, spontaneous seizure rates in mice previously given JNJ-47965567 remained lower (approximately 2 per day), and this was significant compared with vehicle-treated mice $(\mathrm{M}-\mathrm{W}$ statistic $=0.31, p=0.002 ;$ Fig. $3 C)$. Thus, there was a $69 \%$

\footnotetext{
$\leftarrow$

(Figure legend continued.) and graph showing increased P2X7R protein levels in isolated synaptosomes from epileptic mice when compared with control mice. Synaptophysin was used as a loading control ( $n=2$ hippocampi/lane, 5 lanes/group). $\mathbf{G}$, Graph showing the percentage of isolated synaptosomes displaying positive responses to BzATP (30 $\mu \mathrm{M}$ ) administration in control and epileptic synaptosomes $[n=7$ (control) and $n=8$ (epilepsy) coverslips of synaptosomes, generated from three pools of $n=2$ hippocampi $]$. $\boldsymbol{H}$, Representative traces of $\left[\mathrm{Ca}^{2+}\right]_{\text {। }}$ increments elicited by $30 \mu \mathrm{m}$ BzATP and $100 \mathrm{~mm} \mathrm{~K}^{+}$in control (Con) and epileptic (Epi) synaptosome preparations (individual synaptosomes analyzed; Con $=708$, Epi $=990$ ). I, Graph showing the percentage of synaptosomes displaying "multi-responses" after BzATP administration in control and epileptic synaptosomes preparations. Data in $\boldsymbol{E}-\mathbf{G}$ and $\boldsymbol{I}$, Student's $t$ test, ${ }^{*} p<0.05$. ${ }^{* * *} p<0.005$ compared with indicated group.
}

probability of there being fewer seizures in an animal injected with JNJ-47965567 than in an animal injected with vehicle during the washout phase.

The duration of spontaneous seizures was compared between vehicle and JNJ-47965567 using a Mann-Whitney statistic adjusted for clustered observations within animals. There were no differences between groups in the duration of seizures at baseline $(p=0.212)$, during treatment $(p=0.287)$, or during washout $(p=0.419$; Fig. $3 D)$. Representative examples of spontaneous seizures captured using EEG telemetry are shown in Figure $3 E$.

We also undertook additional statistical analysis because of the excess of zeros (no seizures) in the data, using zero-inflated Poisson regression with robust variance estimation to account for the clustering of data within animals. We further examined the excess of zero seizure counts in the treatment phase. This datadriven approach models the data as deriving from the following two populations: a population of animals experiencing seizures in varying numbers, including animals that will experience no seizures during a particular observation period; and a population of animals that are protected from seizures, who will also have zero observed seizures. Thus, observations of zero seizures are a mixture of the two populations. During the on-treatment phase, the zero-inflated Poisson model showed that the JNJ-47965567 group showed a higher incidence of zero seizures than the control group [incidence rate ratio (IRR), $2.5 ; p=0.001$ ]. Although the incidence of seizures, adjusted for this excess of zero scores, was lower in the JNJ-47965567 group (IRR, 0.70), the effect was not significant $(p=0.398)$. During the washout phase, by contrast, there was no evidence of an excess of zero scores in the JNJ47965567-treated animals (IRR, $1.6 ; p=0.184$ ), but there was a lower incidence of seizures in the treated group (IRR, $0.39 ; p=$ $0.008)$.

\section{Clinical seizures during and after treatment with JNJ-47965567}

The behavioral (clinical) features of spontaneous seizures in the animals featured a mixture of partial (focal; score of 1) and secondarily generalized (score of 2) seizures. A selection of up to 10 video-captured seizures was analyzed per mouse during each monitoring period (baseline, on-drug and washout; see Materials and Methods; Fig. 3F). To analyze these data, we used multinomial logistic regression, with SEs adjusted for the clustering of observations within animals. Using a seizure score of 1 (partial) as the reference category, animals in the JNJ-47965567-treated group did not differ from those in the vehicle-treated group in the baseline phase in either the probability of having severe seizures (secondarily generalized) or having no seizures. They had an increased probability of having no seizures both in the treatment phase $(p=0.001)$ and in the washout phase $(p=0.001)$. However, they did not differ from vehicle in the probability of having severe seizures in either the treatment or washout phases. That is, JNJ-47965567 treatment is preventing seizures from occurring rather than altering seizure severity.

\section{JNJ-47965567 treatment reduces microgliosis and astrogliosis in epileptic mice}

Finally, we examined tissue sections from vehicle- and JNJ47965567-treated mice obtained at the end of recordings (i.e., $6 \mathrm{~d}$ after drug treatment ceased). Microgliosis was detected by immunostaining for Iba1, whereas astrocytes were detected by staining for GFAP. As expected, there was widespread microgliosis in tissue sections from epileptic mice given vehicle (Fig. 4A-D). Mi- 
A

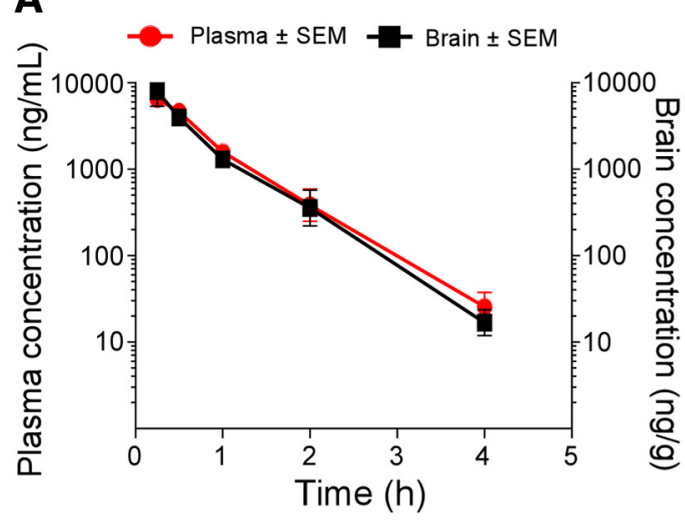

C

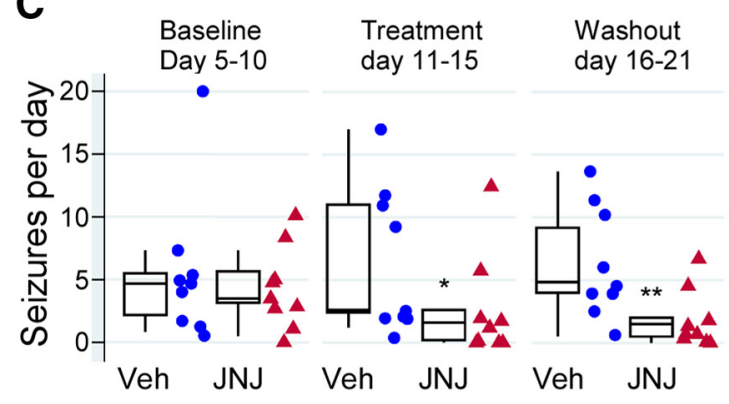

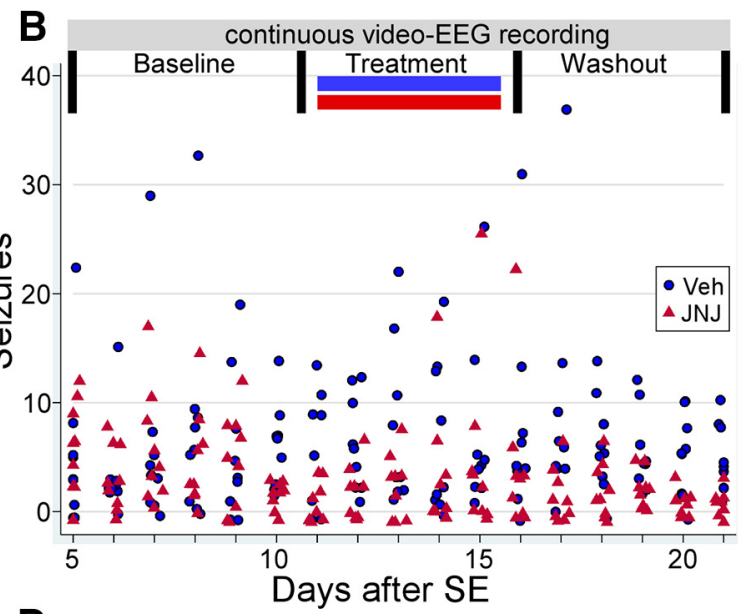

$D$

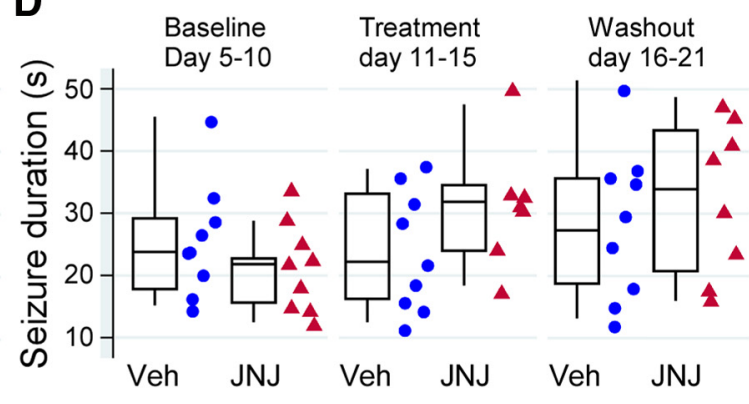

JNJ
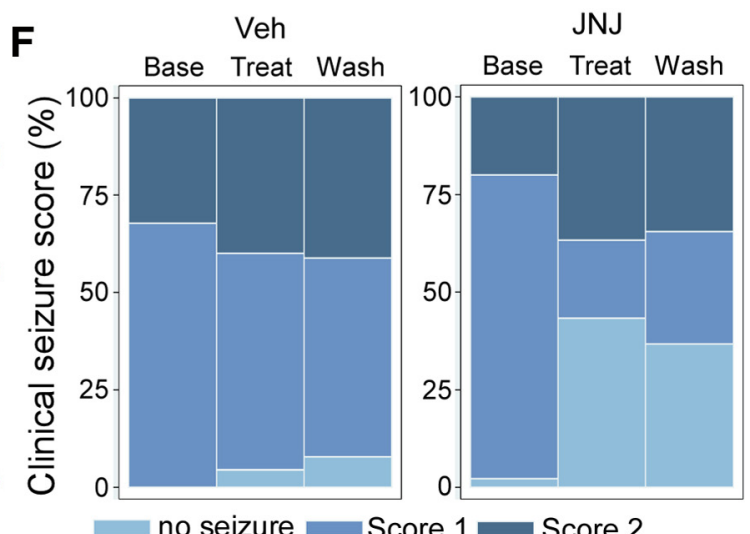

no seizure $=$ Score $1 \cong$ Score 2

E

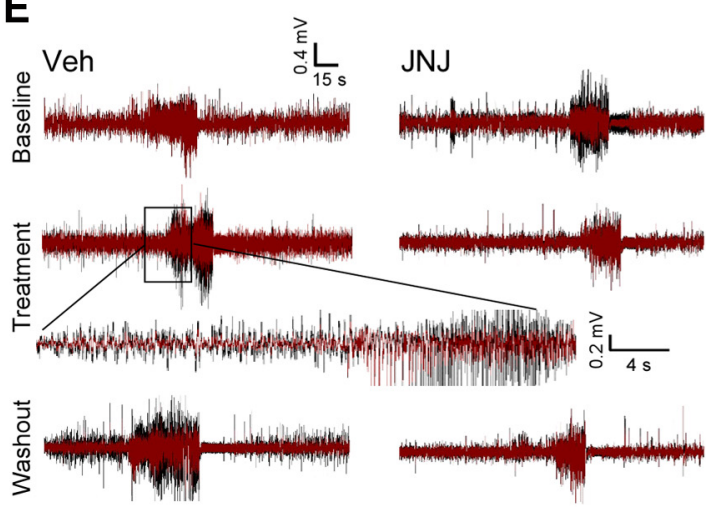

Figure 3. JNJ-47965567 treatment reduces spontaneous seizures in mice. $A$, Plasma and brain concentrations of JNJ-47965567 at various time points after intraperitoneal injection of $30 \mathrm{mg} / \mathrm{kg}$ into naive mice ( $n=3$ per time point). $\boldsymbol{B}$, Experimental design for testing effects of JNJ-47965567 and plots of spontaneous seizures for mice in each group over time. Mice underwent status epilepticus and were then injected twice daily with JNJ-47965567 (30 mg/kg) during days 11-15. Drug/vehicle was discontinued from day 16 until day 21 . Mice were then killed. C, Box plots depicting the average number of seizures per day in vehicle-injected and drug-treated epileptic mice during the baseline days $5-10$ before treatment, days 11-15 during JNJ-47965567 (JNJ) or vehicle (Veh) treatment, and days $16-21$ during washout ( $n=9$ /group; Mann-Whitney statistic adjusted for the clustering of data within animals, $\left.{ }^{*} p<0.05 ;{ }^{* *} p<0.01\right)$. Individual data points plotted beside the boxes are the averaged data for individual mice during each phase of the experiment. $D$, Box plots depicting the average duration of epileptic seizures for each treatment period ( $n=9$ /group; Mann-Whitney statistic adjusted for clustering of data within animals). There were no differences between groups at any phase of the study. Individual data points plotted beside the boxes are the averaged data for individual mice during each phase of the experiment. $\boldsymbol{E}$, Representative examples of spontaneous seizures detected using EEG telemetry at baseline, during treatment and during washout for vehicle-treated and JNJ-47965567-treated mice. Red traces represent the EEG from the contralateral hemisphere, black traces are the EEG from ipsilateral hemisphere. $\boldsymbol{F}$, Clinical scores are depicted as a spine plot. The graphic was based on 10 seizure ratings/animal for each phase of the study (Base, baseline; Treat, treatment; Wash, washout) and were scored as 1 (partial seizure), score 2 secondarily generalized, or no seizure available for a rating. The figure illustrates the comparable severity of seizures when they occurred but with fewer seizures occurring in JNJ-47965567-treated animals.

crogliosis was most prominent in areas of pathology, such as the CA3 subfield, but was also apparent in the CA1 and DG (Fig. $4 A-D)$. In contrast, microgliosis was significantly lower in mice treated with JNJ-47965567 (Fig. 4A-D). Quantification revealed that this reduction was significant in all hippocampal subfields (Fig. 4E). The reduction represented an apparent reduction in the number as well as the immunoreactivity of the $\mathrm{Iba}^{+}$microglia (Fig. 4E).
Last, we assessed astrogliosis in tissue sections stained for GFAP. The hippocampus from epileptic mice given vehicle displayed dramatic astrogliosis (Fig. $4 F-I$ ). This was prominent in all subfields examined, including CA1, CA3, and the DG (Fig. $4 F-I)$. Astrogliosis was lower in all subfields in JNJ-47965567treated mice (Fig. $4 F-J$ ). The reduction represented an apparent reduction in the number as well as the immunoreactivity of the $\mathrm{GFAP}^{+}$astrocytes (Fig. $4 J$ ). 
A

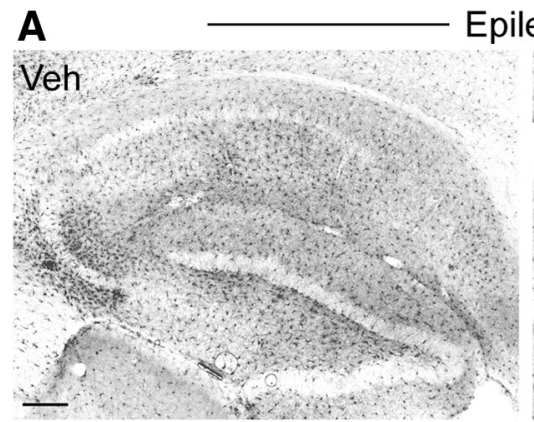

Epilepsy

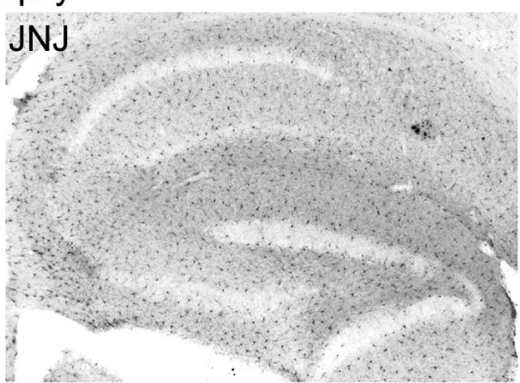

B
CA1

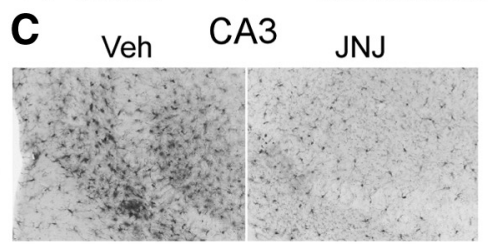

E

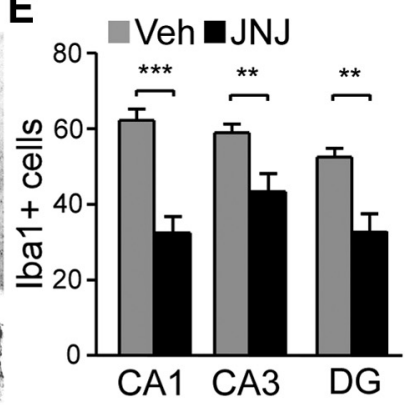

D Veh DG JNJ
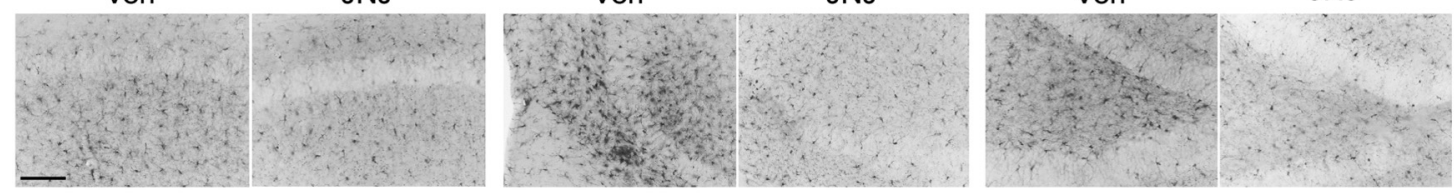

F

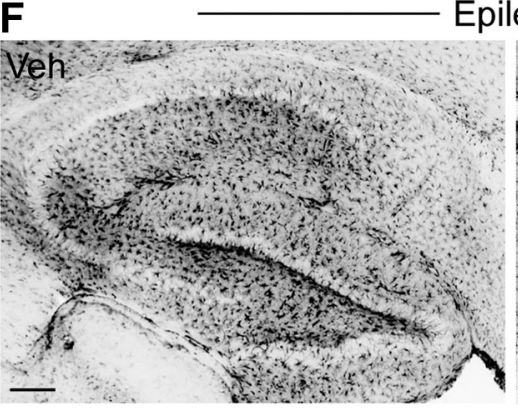

Epilepsy

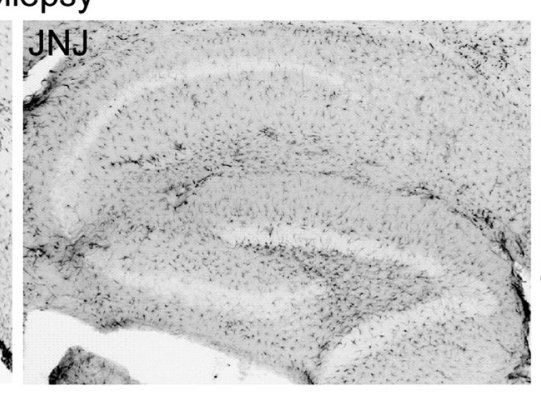

J
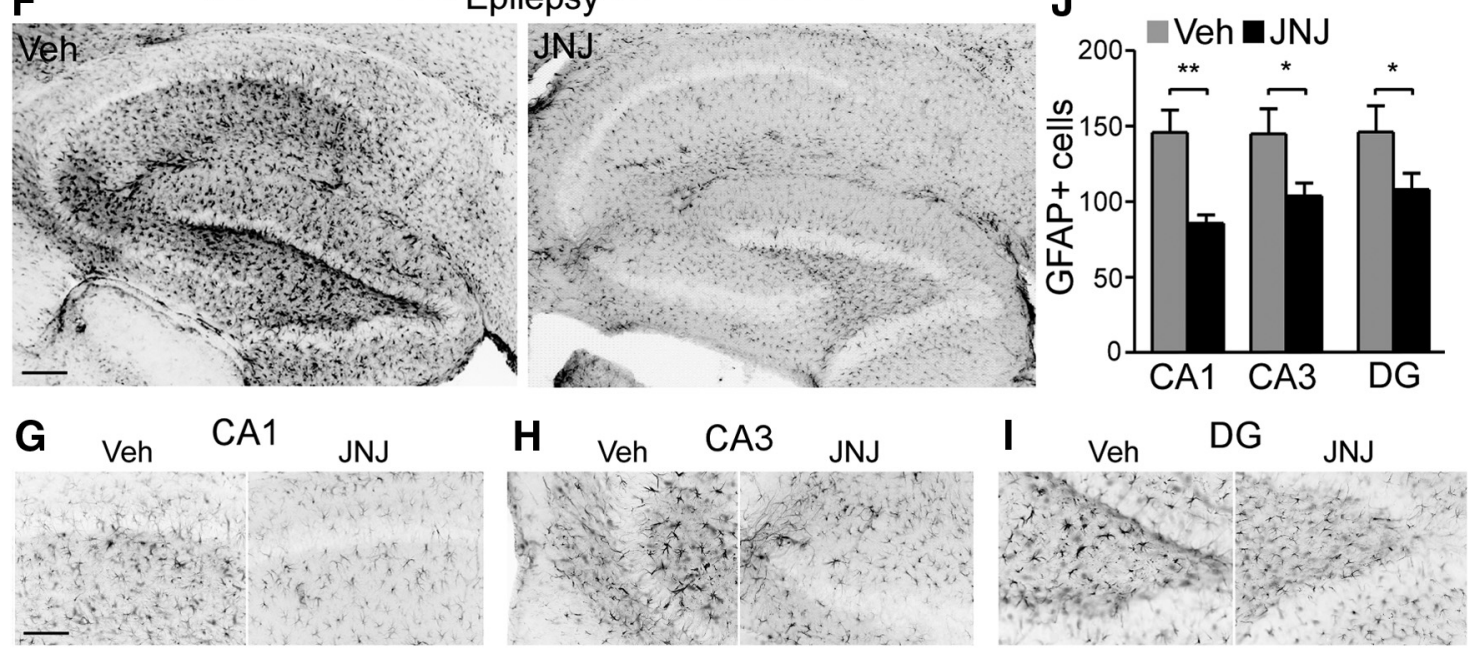

Figure 4. Decreased astrogliosis and microgliosis in JNJ-47965567-treated epileptic mice. $\boldsymbol{A}-\boldsymbol{D}$, Photomicrographs of representative lba1 staining of the hippocampus from vehicle- (Veh) and JNJ-47965567 (JNJ)-treated epileptic mice showing field views $(\boldsymbol{A})$ and $20 \times$ lens magnifications $(\boldsymbol{B}-\boldsymbol{D})$ of individual subfields from the same animal. Note, the decrease in the number of Iba ${ }^{+}{ }^{+}$cells and the immunoreactivity in mice treated with the specific P2X7R inhibitor JNJ-47965567. E, Graph showing the quantification of Iba ${ }^{+}{ }^{+}$microglia found in each hippocampal subfield of vehicleand JNJ-47965567-treated mice killed $6 \mathrm{~d}$ after drug washout at the end of recordings $\left(n=9 /\right.$ group; ANOVA with Bonferroni test, $\left.{ }^{* *} p<0.01,{ }^{* * *} p<0.001\right)$. F-I, Photomicrographs of representative GFAP staining in the hippocampus from vehicle- and JNJ-47965567-treated epileptic mice, showing field views $(\boldsymbol{F})$ and $20 \times$ lens magnifications $(\boldsymbol{G}-\boldsymbol{I})$ of individual subfields from the same animal. J, Quantification of GFAP ${ }^{+}$cells found in each hippocampal subfield from vehicle- and JNJ-47965567-treated mice killed $6 \mathrm{~d}$ after drug washout at the end of recordings $(n=$ 9/group; ANOVA with Bonferroni test, $\left.{ }^{*} p<0.05 .{ }^{* *} p<0.01\right)$. Scale bars: $\boldsymbol{A}, \boldsymbol{F}, 200 \mu \mathrm{m} ; \boldsymbol{B}, \mathbf{G}, 100 \mu \mathrm{m}$.

\section{Discussion}

Current AEDs fail to control seizures in 30\% of patients and do not have an impact on the underlying pathophysiology (Bialer and White, 2010; Pitkänen and Lukasiuk, 2011; Kobow et al., 2012). Thus, there is an unmet need for the novel targetable pathomechanisms that underlie TLE. Altered purinergic signaling has been suggested as a pathomechanism in epilepsy (Burnstock, 2008; Sperlágh and Illes, 2014), and ATP is released after CNS injury at levels sufficient to activate the P2X7R (Wang et al., 2004). P2X7R activation probably serves an important role in the early, protective phase of neuroinflammation by triggering microglia activation and inflammasome-mediated IL- $1 \beta$ release, among other effects (Roth et al., 2014; Sperlágh and Illes, 2014). However, chronic or aberrant P2X7R expression may sustain neuroinflammation, induce neuronal death, and promote hyperexcitability (Murphy et al., 2012; Sperlágh and Illes, 2014; Franceschini et al., 2015). Previous work had found P2X7R overexpression in epilepsy, but the cell types and function of the re- ceptor remained uncertain, and targeting had only been explored in models of acute status epilepticus (Vianna et al., 2002; Rappold et al., 2006; Doná et al., 2009; Kim and Kang, 2011; Engel et al., 2012b; Jimenez-Pacheco et al., 2013). Here we used a reporter mouse to gain insight into the cell phenotypes transcribing the P2rx7 in epilepsy. We found pronounced neuronal transcription in the CA1 and DG subfields, which are less damaged in this model. This is generally consistent with the cellular distribution that emerges in the wake of acute status epilepticus in the same model (Engel et al., 2012b). Other studies may have missed this population due to reliance on immunohistochemical approaches, which lack sensitivity and specificity (Miras-Portugal et al., 2003; Sim et al., 2004; Anderson and Nedergaard, 2006). We also found microglia transcribing $P 2 r x 7$ within the CA3 subfield, which is the main site of neuron loss and the source of spontaneous seizures in the model ( $\mathrm{Li}$ et al., 2008). This is consistent with earlier reports using immunohistochemical approaches in a rat model of TLE (Rappold et al., 2006). Transcrip- 
tion of $P 2 r x 7$ did not appear to occur in astrocytes, which is consistent with other reports (Duan et al., 2003; Jabs et al., 2008; Hirayama et al., 2015). Together, these data suggest that P2rx7 transcriptional responses occur in specific cell populations in a pathology-dependent manner in this model. Functional P2X7R responses were evident from soma recordings from cells with the appearance of neurons in the CA1 and DG, and we also detected $\mathrm{P} 2 \mathrm{X} 7 \mathrm{R}$ responses in synaptosomes, which is consistent with the presynaptic localization reported by others (Armstrong et al., 2002; Vianna et al., 2002; Yu et al., 2008; Engel et al., 2012b). Neuronal P2X7Rs have been reported to influence the release of GABA and glutamate (Armstrong et al., 2002; Sperlágh et al., 2002), and our findings suggest direct neuromodulatory effects of P2X7R that offer a potential explanation for why targeting this receptor alters seizures. That is, blocking neuronal P2X7R may modulate neurotransmitter release and prevent synchronous network firing.

A major finding in the present study was that the treatment of epileptic mice with a P2X7R antagonist reduced the number and duration of spontaneous seizures. The animal model we used features spontaneous seizures at a frequency of approximately six per day with attendant clinical (tonic, clonic) features (Mouri et al., 2008; Jimenez-Mateos et al., 2010; Liu et al., 2013). This has advantages relative to other models for testing AEDs where spontaneous seizures may show marked clustering or are mainly subclinical (Williams et al., 2009; Maroso et al., 2011; Klein et al., 2015). Here we used JNJ-477965567, a recently described centrally available P2X7R antagonist that achieves $~ 98 \%$ brain protein occupancy with an $\mathrm{EC}_{50}$ of $\sim 3 \mathrm{nM}$ (Bhattacharya et al., 2013). Twice-daily injections of JNJ-47965567 reduced spontaneous seizure rates in this model by $>50 \%$ during treatment, although seizure suppression was even more evident after treatment had ceased. This may reflect the time required for the P2X7R inhibitor to result in beneficial effects on the underlying pathophysiology such as gliosis to take effect. This degree of seizure suppression is similar to the effects of conventional AEDs in kainate-induced epilepsy in rodents, including valproate, carbamazepine, topiramate, and levetiracetam (Grabenstatter et al., 2007; Klein et al., 2015). The effect is also comparable to the performance of VX-765, an IL- $1 \beta$ synthesis inhibitor, in the intrahippocampal kainate model in mice (Maroso et al., 2011). Since seizures in focal kainate models of acquired epilepsy are typically refractory to conventional AEDs (Riban et al., 2002; Klein et al., 2015), these data suggest that P2X7R targeting may be suitable as an adjunctive treatment for TLE patients with pharmacoresistant seizures. Indeed, data here and in previous studies of the neocortex (Jimenez-Pacheco et al., 2013) show that the $\mathrm{P} 2 \mathrm{X} 7 \mathrm{R}$ is upregulated in human TLE.

Disease-modifying effects are increasingly recognized as a necessary property of any future AED (Bialer and White, 2010; Kobow et al., 2012). An important and unexpected finding in the present study was that spontaneous seizure rates did not increase once treatment with JNJ-477965567 ended, but remained $\sim 65 \%$ lower (approximately two seizures per day) than in vehicletreated epileptic mice. This cannot be due to the drug remaining in the brain based on the pharmacokinetic data reported here and in previous studies (Bhattacharya et al., 2013). The most likely explanation, therefore, is that JNJ-47965567 had a diseasemodifying effect in the model. This markedly contrasts the results with conventional AEDs in post-status epilepticus models where spontaneous seizure rates, if altered at all, promptly return to baseline on cessation of treatment (Chakir et al., 2006; Grabenstatter et al., 2007; Klein et al., 2015). What is the mechanism of the sustained seizure-suppressive effect of JNJ-477965567? The best understood effect of P2X7R activation is the release of IL- $1 \beta$ from activated microglia. IL- $1 \beta$ is directly proexcitatory via effects on NMDA receptor and driving astrogliosis (Viviani et al., 2003; Allan et al., 2005). However, in studies with VX-765, a direct inhibitor of IL-1 $\beta$ biosynthesis, the number of spontaneous seizures returned to baseline within $24 \mathrm{~h}$ of treatment in mice with kainate-induced epilepsy (Maroso et al., 2011). Thus, the blockade of IL- $1 \beta$ is not a sufficient explanation of the results with JNJ-47965567. A key observation here was that the hippocampus of mice previously treated with JNJ-47965567 displayed marked reductions in both microgliosis and astrogliosis. This not only reduced immunoreactivity but appeared to reduce the numbers of both cell types. This may account for the diseasemodifying effects. Notably, VX-765 does not reduce astrogliosis or microgliosis in epileptic mice (Maroso et al., 2011), and reductions in gliosis are not usually seen after the treatment of rodents with common AEDs (Chakir et al., 2006). The effect on microglia may be due to the drug directly blocking a pathway known to be required for microglia activation (Monif et al., 2009). However, the contribution of microgliosis to spontaneous seizures remains uncertain (Devinsky et al., 2013). The lasting antiseizure effects may also derive from reduced astrogliosis. Indeed, recent studies (Ortinski et al., 2010; Robel et al., 2015) demonstrate that astrogliosis alone, in the absence of other pathology, is sufficient to cause epilepsy in mice. There are several mechanisms by which astrogliosis may promote spontaneous seizures, including depleting endogenous adenosine levels and altering the reuptake of neurotransmitters (Devinsky et al., 2013). Astrocyte-derived ATP may further promote seizures by promoting the release of IL-1 $\beta$ from microglia (Bianco et al., 2005). An additional mechanism underlying the observed effects of JNJ-47965567 may be direct effects on neurotransmitter release (Sperlágh et al., 2002).

A number of limitations should be considered. Despite randomizing animals to the treatment or control group, there was a trend toward less frequent and shorter duration spontaneous seizures during the baseline period in the JNJ-47965567 group, which could predispose this group to being more responsive to treatment. The measurement of brain levels of the mice treated with JNJ-47965567 was performed in healthy mice, but analysis during and after treatment in epileptic mice would provide more valuable insight into the relationship to seizure suppression. Adjustments to the dose, frequency, or duration of treatment with JNJ-47965567 could yield improvements in short-term or longterm seizure suppression. Further experiments will be needed to determine whether the glial changes are a direct or indirect result of blocking P2X7R signaling. We found some disconnect between the transcriptional data from the reporter mouse and $\mathrm{mRNA}$ /protein analysis. This may be due to a nonlinear relationship between EGFP expression and P2rx7 levels, the stability of the channel or reporter protein, a consequence of the microdissection technique, or circuit reorganization in the epileptic hippocampus with loss of neuronal protein balanced by increased glial levels. Another explanation is that post-transcriptional silencing of the P2rx7 in this model, for example by microRNA (Zhou et al., 2008; Jimenez-Mateos et al., 2015), affected the relationship between transcription and protein levels. Last, while ATP release sufficient to activate the P2X7R has been demonstrated after spinal cord injury (Wang et al., 2004), we lack in vivo spatiotemporal data on ATP release during spontaneous seizures. In summary, the present study shows that targeting the P2X7R in experimental epilepsy results in a reduction in spontaneous sei- 
zures and accompanying gliosis. This receptor may represent a novel target for the treatment of refractory TLE.

\section{References}

Abbracchio MP, Burnstock G, Verkhratsky A, Zimmermann H (2009) Purinergic signalling in the nervous system: an overview. Trend Neurosci 32:19-29. CrossRef Medline

Allan SM, Tyrrell PJ, Rothwell NJ (2005) Interleukin-1 and neuronal injury. Nat Rev Immunol 5:629-640. CrossRef Medline

Anderson CM, Nedergaard M (2006) Emerging challenges of assigning $\mathrm{P} 2 \mathrm{X} 7$ receptor function and immunoreactivity in neurons. Trend Neurosci 29:257-262. CrossRef Medline

Armstrong JN, Brust TB, Lewis RG, MacVicar BA (2002) Activation of presynaptic P2X7-like receptors depresses mossy fiber-CA3 synaptic transmission through p38 mitogen-activated protein kinase. J Neurosci 22: 5938-5945. Medline

Bhattacharya A, Wang Q, Ao H, Shoblock JR, Lord B, Aluisio L, Fraser I, Nepomuceno D, Neff RA, Welty N, Lovenberg TW, Bonaventure P, Wickenden AD, Letavic MA (2013) Pharmacological characterization of a novel centrally permeable P2X7 receptor antagonist: JNJ-47965567. Br J Pharmacol 170:624-640. CrossRef Medline

Bialer M, White HS (2010) Key factors in the discovery and development of new antiepileptic drugs. Nat Rev Drug Discov 9:68-82. CrossRef Medline

Bianco F, Pravettoni E, Colombo A, Schenk U, Möller T, Matteoli M, Verderio C (2005) Astrocyte-derived ATP induces vesicle shedding and IL-1 beta release from microglia. J Immunol 174:7268-7277. CrossRef Medline

Block ML, Zecca L, Hong JS (2007) Microglia-mediated neurotoxicity: uncovering the molecular mechanisms. Nat Rev Neurosci 8:57-69. CrossRef Medline

Burnstock G (2008) Purinergic signalling and disorders of the central nervous system. Nat Rev Drug Discov 7:575-590. CrossRef Medline

Chakir A, Fabene PF, Ouazzani R, Bentivoglio M (2006) Drug resistance and hippocampal damage after delayed treatment of pilocarpine-induced epilepsy in the rat. Brain Res Bull 71:127-138. CrossRef Medline

Devinsky O, Vezzani A, Najjar S, De Lanerolle NC, Rogawski MA (2013) Glia and epilepsy: excitability and inflammation. Trend Neurosci 36:174184. CrossRef Medline

Díaz-Hernández M, Pintor J, Castro E, Miras-Portugal MT (2001a) Independent receptors for diadenosine pentaphosphate and ATP in rat midbrain single synaptic terminals. Eur J Neurosci 14:918-926. CrossRef Medline

Díaz-Hernández M, Gómez-Villafuertes R, Hernando F, Pintor J, MirasPortugal MT (2001b) Presence of different ATP receptors on rat midbrain single synaptic terminals. Involvement of the P2X(3) subunits. Neurosci Lett 301:159-162. CrossRef Medline

Doná F, Ulrich H, Persike DS, Conceição IM, Blini JP, Cavalheiro EA, Fernandes MJ (2009) Alteration of purinergic P2X4 and P2X7 receptor expression in rats with temporal-lobe epilepsy induced by pilocarpine. Epilepsy Res 83:157-167. CrossRef Medline

Duan S, Anderson CM, Keung EC, Chen Y, Chen Y, Swanson RA (2003) $\mathrm{P} 2 \mathrm{X} 7$ receptor-mediated release of excitatory amino acids from astrocytes. J Neurosci 23:1320-1328. Medline

Eltzschig HK, Sitkovsky MV, Robson SC (2013) Purinergic signaling during inflammation. N Engl J Med 368:1260. CrossRef Medline

Engel T, Jimenez-Pacheco A, Miras-Portugal MT, Diaz-Hernandez M, Henshall DC (2012a) P2X7 receptor in epilepsy; role in pathophysiology and potential targeting for seizure control. Int J Physiol Pathophysiol Pharmacol 4:174-187. Medline

Engel T, Gomez-Villafuertes R, Tanaka K, Mesuret G, Sanz-Rodriguez A, Garcia-Huerta P, Miras-Portugal MT, Henshall DC, Diaz-Hernandez M (2012b) Seizure suppression and neuroprotection by targeting the purinergic P2X7 receptor during status epilepticus in mice. FASEB J 26:16161628. CrossRef Medline

Engel T, Sanz-Rodgriguez A, Jimenez-Mateos EM, Concannon CG, JimenezPacheco A, Moran C, Mesuret G, Petit E, Delanty N, Farrell MA, O’Brien DF, Prehn JH, Lucas JJ, Henshall DC (2013) CHOP regulates the p53MDM2 axis and is required for neuronal survival after seizures. Brain 136:577-592. CrossRef Medline

Fellin T, Pozzan T, Carmignoto G (2006) Purinergic receptors mediate two distinct glutamate release pathways in hippocampal astrocytes. J Biol Chem 281:4274-4284. CrossRef Medline
Fisher RS, Acevedo C, Arzimanoglou A, Bogacz A, Cross JH, Elger CE, Engel J Jr, Forsgren L, French JA, Glynn M, Hesdorffer DC, Lee BI, Mathern GW, Moshé SL, Perucca E, Scheffer IE, Tomson T, Watanabe M, Wiebe S (2014) ILAE official report: a practical clinical definition of epilepsy. Epilepsia 55:475-482. CrossRef Medline

Franceschini A, Capece M, Chiozzi P, Falzoni S, Sanz JM, Sarti AC, Bonora M, Pinton P, Di Virgilio F (2015) The P2X7 receptor directly interacts with the NLRP3 inflammasome scaffold protein. FASEB J 29:2450-2461. CrossRef Medline

Grabenstatter HL, Clark S, Dudek FE (2007) Anticonvulsant effects of carbamazepine on spontaneous seizures in rats with kainate-induced epilepsy: comparison of intraperitoneal injections with drug-in-food protocols. Epilepsia 48:2287-2295. CrossRef Medline

Haydon PG, Carmignoto G (2006) Astrocyte control of synaptic transmission and neurovascular coupling. Physiol Rev 86:1009-1031. CrossRef Medline

Hirayama Y, Ikeda-Matsuo Y, Notomi S, Enaida H, Kinouchi H, Koizumi S (2015) Astrocyte-mediated ischemic tolerance. J Neurosci 35:37943805. CrossRef Medline

Idzko M, Ferrari D, Eltzschig HK (2014) Nucleotide signalling during inflammation. Nature 509:310-317. CrossRef Medline

Jabs R, Matthias K, Grote A, Grauer M, Seifert G, Steinhäuser C (2007) Lack of P2X receptor mediated currents in astrocytes and GluR type glial cells of the hippocampal CA1 region. Glia 55:1648-1655. CrossRef Medline

Jabs R, Seifert G, Steinhäuser C (2008) Astrocytic function and its alteration in the epileptic brain. Epilepsia 49 [Suppl 2]:3-12. CrossRef

Jimenez-Mateos EM, Mouri G, Conroy RM, Henshall DC (2010) Epileptic tolerance is associated with enduring neuroprotection and uncoupling of the relationship between CA3 damage, neuropeptide Y rearrangement and spontaneous seizures following intra-amygdala kainic acid-induced status epilepticus in mice. Neuroscience 171:556-565. CrossRef Medline Jimenez-Mateos EM, Arribas-Blazquez M, Sanz-Rodriguez A, Concannon C, Olivos-Ore LA, Reschke CR, Mooney CM, Mooney C, Lugara E, Morgan J, Langa E, Jimenez-Pacheco A, Silva LF, Mesuret G, Boison D, MirasPortugal MT, Letavic M, Artalejo AR, Bhattacharya A, Diaz-Hernandez M, et al. (2015) MicroRNA targeting of the P2X7 purinoceptor opposes a contralateral epileptogenic focus in the hippocampus. Sci Rep 5:17486. CrossRef Medline

Jimenez-Pacheco A, Mesuret G, Sanz-Rodriguez A, Tanaka K, Mooney C, Conroy R, Miras-Portugal MT, Diaz-Hernandez M, Henshall DC, Engel $\mathrm{T}$ (2013) Increased neocortical expression of the P2X7 receptor after status epilepticus and anticonvulsant effect of P2X7 receptor antagonist A-438079. Epilepsia 54:1551-1561. CrossRef Medline

Johnson MR, Behmoaras J, Bottolo L, Krishnan ML, Pernhorst K, Santoscoy PL, Rossetti T, Speed D, Srivastava PK, Chadeau-Hyam M, Hajji N, Dabrowska A, Rotival M, Razzaghi B, Kovac S, Wanisch K, Grillo FW, Slaviero A, Langley SR, Shkura K, et al. (2015) Systems genetics identifies Sestrin 3 as a regulator of a proconvulsant gene network in human epileptic hippocampus. Nat Commun 6:6031. CrossRef Medline

Kim JE, Kang TC (2011) The P2X7 receptor-pannexin-1 complex decreases muscarinic acetylcholine receptor-mediated seizure susceptibility in mice. J Clin Invest 121:2037-2047. CrossRef Medline

Klein S, Bankstahl M, Löscher W (2015) Inter-individual variation in the effect of antiepileptic drugs in the intrahippocampal kainate model of mesial temporal lobe epilepsy in mice. Neuropharmacology 90:53-62. CrossRef Medline

Kobow K, Auvin S, Jensen F, Löscher W, Mody I, Potschka H, Prince D, Sierra A, Simonato M, Pitkänen A, Nehlig A, Rho JM (2012) Finding a better drug for epilepsy: antiepileptogenesis targets. Epilepsia 53:1868-1876. CrossRef Medline

Li T, Quan Lan J, Fredholm BB, Simon RP, Boison D (2007) Adenosine dysfunction in astrogliosis: cause for seizure generation? Neuron Glia Biol 3:353-366. CrossRef Medline

Li T, Ren G, Lusardi T, Wilz A, Lan JQ, Iwasato T, Itohara S, Simon RP, Boison D (2008) Adenosine kinase is a target for the prediction and prevention of epileptogenesis in mice. J Clin Invest 118:571-582. CrossRef Medline

Liu G, Gu B, He XP, Joshi RB, Wackerle HD, Rodriguiz RM, Wetsel WC, McNamara JO (2013) Transient inhibition of TrkB kinase after status epilepticus prevents development of temporal lobe epilepsy. Neuron 79: 31-38. CrossRef Medline 
Marchi N, Granata T, Janigro D (2014) Inflammatory pathways of seizure disorders. Trend Neurosci 37:55-65. CrossRef Medline

Maroso M, Balosso S, Ravizza T, Iori V, Wright CI, French J, Vezzani A (2011) Interleukin-1beta biosynthesis inhibition reduces acute seizures and drug resistant chronic epileptic activity in mice. Neurotherapeutics 8:304-315. CrossRef Medline

Mesuret G, Engel T, Hessel EV, Sanz-Rodriguez A, Jimenez-Pacheco A, Miras-Portugal MT, Diaz-Hernandez M, Henshall DC (2014) P2X7 receptor inhibition interrupts the progression of seizures in immature rats and reduces hippocampal damage. CNS Neurosci Ther 20:556-564. CrossRef Medline

Miras-Portugal MT, Díaz-Hernández M, Giráldez L, Hervás C, GómezVillafuertes R, Sen RP, Gualix J, Pintor J (2003) P2X7 receptors in rat brain: presence in synaptic terminals and granule cells. Neurochem Res 28:1597-1605. CrossRef Medline

Monif M, Reid CA, Powell KL, Smart ML, Williams DA (2009) The P2X7 receptor drives microglial activation and proliferation: a trophic role for P2X7R pore. J Neurosci 29:3781-3791. CrossRef Medline

Moshé SL, Perucca E, Ryvlin P, Tomson T (2015) Epilepsy: new advances. Lancet 385:884-898. CrossRef Medline

Mouri G, Jimenez-Mateos E, Engel T, Dunleavy M, Hatazaki S, Paucard A, Matsushima S, Taki W, Henshall DC (2008) Unilateral hippocampal CA3-predominant damage and short latency epileptogenesis after intraamygdala microinjection of kainic acid in mice. Brain Res 1213:140-151. CrossRef Medline

Murphy N, Cowley TR, Richardson JC, Virley D, Upton N, Walter D, Lynch MA (2012) The neuroprotective effect of a specific P2X(7) receptor antagonist derives from its ability to inhibit assembly of the NLRP3 inflammasome in glial cells. Brain Pathol 22:295-306. CrossRef Medline

Narkilahti S, Nissinen J, Pitkänen A (2003) Administration of caspase 3 inhibitor during and after status epilepticus in rat: effect on neuronal damage and epileptogenesis. Neuropharmacology 44:1068-1088. CrossRef Medline

Newson R (2006a) Confidence intervals for rank statistics: Somers' D and extensions. Stata J 6:309-334.

Newson R (2006b) Confidence intervals for rank statistics: percentile slopes, differences, and ratios. Stata J 6:497-520.

Ortinski PI, Dong J, Mungenast A, Yue C, Takano H, Watson DJ, Haydon PG, Coulter DA (2010) Selective induction of astrocytic gliosis generates deficits in neuronal inhibition. Nat Neurosci 13:584-591. CrossRef Medline

Pitkänen A, Lukasiuk K (2011) Mechanisms of epileptogenesis and potential treatment targets. Lancet Neurol 10:173-186. CrossRef Medline

Pusch M, Neher E (1988) Rates of diffusional exchange between small cells and a measuring patch pipette. Pflugers Arch 411:204-211. CrossRef Medline

Rappold PM, Lynd-Balta E, Joseph SA (2006) P2X7 receptor immunoreactive profile confined to resting and activated microglia in the epileptic brain. Brain Res 1089:171-178. CrossRef Medline

Riban V, Bouilleret V, Pham-Lê BT, Fritschy JM, Marescaux C, Depaulis A (2002) Evolution of hippocampal epileptic activity during the development of hippocampal sclerosis in a mouse model of temporal lobe epilepsy. Neuroscience 112:101-111. CrossRef Medline

Robel S, Buckingham SC, Boni JL, Campbell SL, Danbolt NC, Riedemann T,
Sutor B, Sontheimer H (2015) Reactive astrogliosis causes the development of spontaneous seizures. J Neurosci 35:3330-3345. CrossRef Medline

Roth TL, Nayak D, Atanasijevic T, Koretsky AP, Latour LL, McGavern DB (2014) Transcranial amelioration of inflammation and cell death after brain injury. Nature 505:223-228. CrossRef Medline

Salter MW, Beggs S (2014) Sublime microglia: expanding roles for the guardians of the CNS. Cell 158:15-24. CrossRef Medline

Sim JA, Young MT, Sung HY, North RA, Surprenant A (2004) Reanalysis of P2X7 receptor expression in rodent brain. J Neurosci 24:6307-6314. CrossRef Medline

Soni N, Koushal P, Reddy BV, Deshmukh R, Kumar P (2015) Effect of GLT-1 modulator and P2X7 antagonists alone and in combination in the kindling model of epilepsy in rats. Epilepsy Behav 48:4-14. CrossRef Medline

Sperlágh B, Illes P (2014) P2X7 receptor: an emerging target in central nervous system diseases. Trends Pharmacol Sci 35:537-547. CrossRef Medline

Sperlágh B, Köfalvi A, Deuchars J, Atkinson L, Milligan CJ, Buckley NJ, Vizi ES (2002) Involvement of P2X7 receptors in the regulation of neurotransmitter release in the rat hippocampus. J Neurochem 81:11961211. CrossRef Medline

Surprenant A, North RA (2009) Signaling at purinergic P2X receptors. Annu Rev Physiol 71:333-359. CrossRef Medline

Vezzani A, Balosso S, Maroso M, Zardoni D, Noé F, Ravizza T (2010) ICE/ caspase 1 inhibitors and IL-1beta receptor antagonists as potential therapeutics in epilepsy. Curr Opin Investig Drugs 11:43-50. Medline

Vezzani A, French J, Bartfai T, Baram TZ (2011) The role of inflammation in epilepsy. Nat Rev Neurology 7:31-40. CrossRef Medline

Vianna EP, Ferreira AT, Naffah-Mazzacoratti MG, Sanabria ER, Funke M, Cavalheiro EA, Fernandes MJ (2002) Evidence that ATP participates in the pathophysiology of pilocarpine-induced temporal lobe epilepsy: fluorimetric, immunohistochemical, and Western blot studies. Epilepsia 43 [Suppl 5]:227-229.

Viviani B, Bartesaghi S, Gardoni F, Vezzani A, Behrens MM, Bartfai T, Binaglia M, Corsini E, Di Luca M, Galli CL, Marinovich M (2003) Interleukin- $1 \beta$ enhances NMDA receptor-mediated intracellular calcium increase through activation of the Src family of kinases. J Neurosci 23 : 8692-8700. Medline

Wang X, Arcuino G, Takano T, Lin J, Peng WG, Wan P, Li P, Xu Q, Liu QS, Goldman SA, Nedergaard M (2004) P2X7 receptor inhibition improves recovery after spinal cord injury. Nat Med 10:821-827. CrossRef Medline

Williams PA, White AM, Clark S, Ferraro DJ, Swiercz W, Staley KJ, Dudek FE (2009) Development of spontaneous recurrent seizures after kainateinduced status epilepticus. J Neurosci 29:2103-2112. CrossRef Medline

Yu Y, Ugawa S, Ueda T, Ishida Y, Inoue K, Kyaw Nyunt A, Umemura A, Mase M, Yamada K, Shimada S (2008) Cellular localization of P2X7 receptor mRNA in the rat brain. Brain Res 1194:45-55. CrossRef Medline

Zhou L, Qi X, Potashkin JA, Abdul-Karim FW, Gorodeski GI (2008) MicroRNAs miR-186 and miR-150 downregulate expression of the proapoptotic purinergic $\mathrm{P} 2 \mathrm{X} 7$ receptor by activation of instability sites at the $3^{\prime}$-untranslated region of the gene that decrease steady-state levels of the transcript. J Biol Chem 283:28274-28286. CrossRef Medline 